Portland State University

PDXScholar

\title{
Evaluation of Short Duration Unscheduled Absences Among Transit Operators: TriMet Case Study
}

James G. Strathman

Portland State University

Joseph Broach

Portland State University

Steve Callas

TriMet

Follow this and additional works at: https://pdxscholar.library.pdx.edu/usp_fac

Part of the Transportation Commons, Urban Studies Commons, and the Urban Studies and Planning Commons

Let us know how access to this document benefits you.

\section{Citation Details}

Strathman, James G., Joseph Broach, and Steve Callas. Evaluation of Short Duration Unscheduled Absences Among Transit Operators: TriMet Case Study. OTREC-RR-09-05. Portland, OR: Transportation Research and Education Center (TREC), 2009. http://dx.doi.org/10.15760/trec.141

This Report is brought to you for free and open access. It has been accepted for inclusion in Urban Studies and Planning Faculty Publications and Presentations by an authorized administrator of PDXScholar. Please contact us if we can make this document more accessible: pdxscholar@pdx.edu. 


\section{SOTREC}

FINAL REPORT

\section{Evaluation of Short Duration Unscheduled Absences Among Transit Operators: TriMet Case Study}

OTREC-RR-09-05 September 2009 



\title{
EVALUATION OF SHORT-DURATION, UNSCHEDULED ABSENCES AMONG TRANSIT OPERATORS: TRIMET CASE STUDY
}

\author{
Final Report \\ OTREC-RR-09-05 \\ by \\ James G. Strathman \\ Joseph Broach \\ Center for Urban Studies \\ Portland State University \\ Portland, OR 97207
}

\author{
Steve Callas \\ TriMet \\ 4012 S.E. $17^{\text {th }}$ Ave. \\ Portland, OR 97202
}

for

Oregon Transportation Research

and Education Consortium (OTREC)

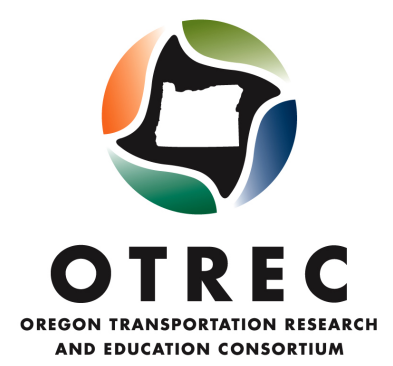

September 2009 



\begin{tabular}{|c|c|c|c|c|c|}
\hline \multicolumn{6}{|c|}{ Technical Report Documentation Page } \\
\hline $\begin{array}{l}\text { 1. Report No. } \\
\text { OTREC-RR-09-05 }\end{array}$ & \multicolumn{3}{|c|}{ 2. Government Accession No. } & \multicolumn{2}{|c|}{ 3. Recipient's Catalog No. } \\
\hline \multirow{2}{*}{\multicolumn{4}{|c|}{$\begin{array}{l}\text { 4. Title and Subtitle } \\
\text { Evaluation of Short Duration Unscheduled Absences Among Transit Operators: } \\
\text { TriMet Case Study }\end{array}$}} & \multicolumn{2}{|c|}{$\begin{array}{l}\text { 5. Report Date } \\
\text { September } 2009\end{array}$} \\
\hline & & & & \multicolumn{2}{|c|}{$\begin{array}{l}\text { 6. Performing Organization } \\
\text { Code }\end{array}$} \\
\hline \multicolumn{4}{|c|}{$\begin{array}{l}\text { 7. Author(s) } \\
\text { James G. Strathman, Joseph Broach, and Steve Callas }\end{array}$} & \multicolumn{2}{|c|}{$\begin{array}{l}\text { 8. Performing Organization } \\
\text { Report No. }\end{array}$} \\
\hline \multirow{2}{*}{\multicolumn{4}{|c|}{$\begin{array}{l}\text { 9. Performing Organization Name and Address } \\
\text { Center for Urban Studies } \\
\text { Portland State University } \\
\text { Portland, OR } 97207\end{array}$}} & \multicolumn{2}{|c|}{ 10. Work Unit No. (TRAIS) } \\
\hline & & & & \multicolumn{2}{|c|}{ 11. Contract or Grant No. } \\
\hline \multirow{2}{*}{\multicolumn{4}{|c|}{$\begin{array}{l}\text { 12. Sponsoring Agency Name and Address } \\
\text { Oregon Transportation Research } \\
\text { and Education Consortium (OTREC) } \\
\text { P.O. Box } 751 \\
\text { Portland, Oregon } 97207\end{array}$}} & \multicolumn{2}{|c|}{$\begin{array}{l}\text { 13. Type of Report and Period } \\
\text { Covered }\end{array}$} \\
\hline & & & & \multicolumn{2}{|c|}{ 14. Sponsoring Agency Code } \\
\hline \multicolumn{6}{|c|}{ 15. Supplementary Notes } \\
\hline \multicolumn{6}{|c|}{$\begin{array}{l}\text { 16. Abstract } \\
\text { This report analyzes factors contributing to short duration (one to three days) unscheduled absences among operators } \\
\text { at TriMet, the transit provider for the Portland, Oregon metropolitan region. The analysis draws on a wide array of } \\
\text { operator-specific information recovered by transit ITS technologies in combination with information from the } \\
\text { agency's human resources, scheduling, incident, and customer relations databases. The likelihood of an absence is } \\
\text { estimated in relation to personal characteristics, employment status, aspects of assigned work, service delivery and } \\
\text { performance indicators, temporal factors, and customer feedback. The findings can be used directly to support } \\
\text { extraboard planning practices. More generally, the findings point to changes in policies and practices that would } \\
\text { potentially reduce the incidence of short duration absences. }\end{array}$} \\
\hline \multicolumn{2}{|l|}{$\begin{array}{l}\text { 17. Key Words } \\
\text { Transit Operators, Absenteeism }\end{array}$} & \multicolumn{4}{|c|}{$\begin{array}{l}\text { 18. Distribution Statement } \\
\text { No restrictions. Copies available from } \\
\text { OTREC: www.otrec.us }\end{array}$} \\
\hline $\begin{array}{l}\text { 19. Security Classification (of this } \\
\text { report) } \\
\text { Unclassified }\end{array}$ & $\begin{array}{l}\text { 20. Security Clas } \\
\text { page) } \\
\text { Unclassified }\end{array}$ & (of this & $\begin{array}{r}21 . \\
5\end{array}$ & To. of Pages & 22. Price \\
\hline
\end{tabular}





\section{ACKNOWLEDGEMENTS}

The authors gratefully acknowledge the financial support provided by the Oregon Transportation Research and Education Consortium (OTREC) and by TriMet.

\section{DISCLAIMER}

The contents of this report reflect the views of the authors, who are solely responsible for the facts and the accuracy of the material and information presented herein. This document is disseminated under the sponsorship of the U.S. Department of Transportation University Transportation Centers Program and TriMet in the interest of information exchange. The U.S. Government and TriMet assume no liability for the contents or use thereof. The contents do not necessarily reflect the official views of the U.S. Government and TriMet. This report does not constitute a standard, specification, or regulation. 



\section{Table of Contents}

\begin{tabular}{|c|c|}
\hline & \\
\hline 1.0 & INTRODUCTION............. \\
\hline 2.0 & REVIEW OF PRIOR RESEARCH. \\
\hline 2.1 & 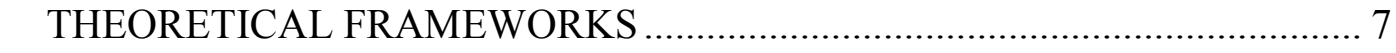 \\
\hline 2.2 & EMPIRICAL FINDINGS................... \\
\hline 2.3 & TRANSIT OPERATING ENVIRONMENT AND STRESS ............................ 14 \\
\hline 3.0 & DATA AND MODEL \\
\hline 4.0 & 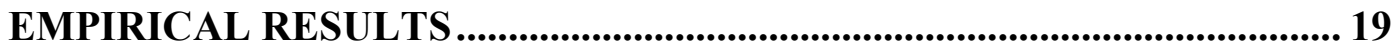 \\
\hline 4.1 & PERSONAL CHARACTERISTICS AND EMPLOYMENT STATUS ............ 19 \\
\hline 4.2 & ASSIGNED WORK \\
\hline 4.3 & 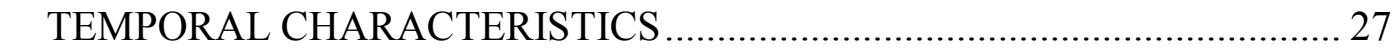 \\
\hline 4.4 & SERVICE DELIVERY CHARACTERISTICS...... \\
\hline 4.5 & 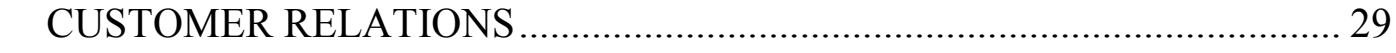 \\
\hline 4.6 & OPERATOR FIXED EFFECTS ................ \\
\hline 4.7 & OVERALL MODEL PERFORMANCE.. \\
\hline & CONCLUSIONS \\
\hline 0 & 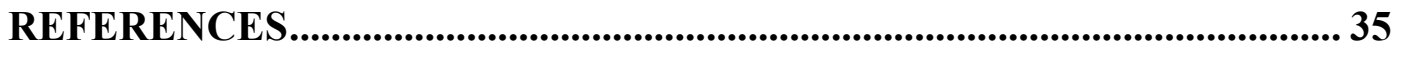 \\
\hline
\end{tabular}

\section{Appendices}

Appendix A: Variable Descriptions and Descriptive Statistics for Bus and Rail Operator Samples

\section{List of Tables}

Table 1: Key Features of Multivariate Absence Studies ................................................. 10

Table 2: Effects of Selected Variables From Multivariate Absence Studies ..................... 11

Table 3: Operator Absence Model Parameter Estimates (t-values in parentheses) .......... 21

\section{List of Figures}

Figure 1: Frequency Distribution of Absence Model Operator Fixed Effects. 



\section{EXECUTIVE SUMMARY}

Transit providers maintain a reserve pool of operators, known as extraboards, to fill work assignments when regular-duty operators are absent. The extraboard planning process (or "sizing the extraboard") must anticipate the amount of open work that will need to be filled. Sizing the extraboard is thus an exercise in predicting absences among regularduty operators. Important consequences follow when the size of the extraboard does not match the amount of work that needs to be filled. Missed pull-outs occur when the open work exceeds the available extraboard. Alternatively, when the available extraboard exceeds the amount of open work, surplus operators must be paid for services that customers never see. In either case, a cost is imposed, borne either by customers or the service provider.

Short-duration absences, extending from one to three days, account for most of the dayto-day variation in the amount of open work that must be filled by extraboard operators. Both the general incidence and the variability of short-duration operator absences have increased since the implementation of the Family and Medical Leave Act (FMLA) of 1993. The U.S. Department of Labor has identified the transit industry as being among the most affected by FMLA regulations on unscheduled intermittent leaves associated with serious medical conditions. FMLA regulations currently allow workers to notify their employer of such leaves up to two days after their occurrence.

Given the increasing frequency and daily volatility of short-duration absences, there is a need to gain a better understanding of their systematic occurrence in order to support extraboard planning efforts. Apart from facilitating the planning process, improving our understanding of factors that contribute to short-duration absences may also help in identifying changes in policies or practices that would reduce their incidence. Beyond our direct interest in extraboard planning, research indicates that short-term absences represent an early indicator of more serious subsequent conditions, such as medical disabilities, and can also lead to premature resignations.

This report examines patterns of short-duration absences at TriMet, the transit provider for the Portland, OR, metropolitan area. It is distinguished from previous absence studies in the transit industry by its use of operator-specific information recovered from ITS technologies that have become widely deployed in the transit industry. The analysis integrates ITS data with information from TriMet's human resource, scheduling, incident, and customer relations databases.

A statistical model is estimated, relating daily attendance or absence to operators' personal characteristics, employment status, characteristics of assigned work, indicators associated with the delivery of service, and customer comments related to operators and service delivery. The sample analyzed covers 1,362 bus and 175 light-rail regular-duty operators and their daily work in 2006 and 2007. 
Findings from the statistical analysis show the influence of a variety of factors contributing to absence patterns among operators. Regarding personal characteristics, absence likelihoods are highest among Caucasian operators and decline progressively for African-Americans, Asians, and Hispanics. Absence likelihoods are estimated to be higher for women than for men. Regarding employment status, full-time operators are estimated to have a higher absence likelihood than part-time and probationary operators. Absence likelihoods are estimated to increase with seniority, but this is more than offset by estimated declines with respect to operator age.

Among the assigned work characteristics, operators on regular-relief and straight-run assignments are estimated to have the lowest absence likelihood, while the absence likelihoods of those with split shifts (both full- and part-time) are the highest. Assigned runs that conclude before 5 p.m. have lower estimated absence likelihoods than runs that conclude in the evening or nighttime hours. Estimated absence likelihoods vary by day of the week, with Thursdays, Fridays, and Saturdays being the highest. Absence likelihoods also are estimated to jump on the day before an operator's regular day off. Seasonality is apparent, with absence likelihoods estimated to reach a peak in December, January, and February, and a trough in the April-to-September period.

Among the service delivery variables, on-time performance is found to be an important absence indicator. Operators who are consistently late in departures from time points compared to their peers are estimated to have a higher absence likelihood. Other factors contributing positively to absence likelihoods are speeding and higher volumes of passenger movements and lift operations. The recent occurrence of selected events was also found to have positive effects on absence likelihoods. Such events included security response requests, having to take evasive action, vehicle malfunctions, and lost service.

In the area of customer relations, a pattern of recent complaints related to the safe operation of a vehicle, the timeliness or availability of service, or customers' treatment by the operator each were estimated to have a positive effect on absence likelihoods. A recent incident involving a question of an operator's fitness for duty, whether initiated from a customer contact or other source, also was estimated to positively affect the estimated absence likelihood.

The statistical model provides a basis for estimating short-duration absences in support of the extraboard planning process. Findings from the analysis also indicate the possible attendance benefits that would follow from several policy changes. First, allowing operators to switch from full-time to part-time status without losing their seniority rights would be beneficial to several operator groups. These groups include senior operators, who might be induced to return to service on a part-time basis after retirement, and women operators, who may find the option of part-time service to be a better fit in balancing their work and non-work responsibilities.

Second, economic incentives promoting attendance have proven effective elsewhere. The current arrangement, where operators cash out unused sick leave at retirement, 
however, may be of limited present value to the most absence-prone operators, who are many years away from retirement age. An alternative program that moves payments for good attendance closer to the present may provide a stronger inducement. 



\subsection{INTRODUCTION}

Transit providers maintain a reserve pool of operators, known as extraboards, to fill work assignments when regular-duty operators are absent. The extraboard planning process (or "sizing the extraboard") must anticipate the amount of work that will need to be filled over the course of a three- to four-month service period. Sizing the extraboard is thus an exercise in predicting absences among regular-duty operators. Important consequences follow when the size of the extraboard does not match the amount of work that needs to be filled. Missed pull-outs occur when the open work exceeds the available extraboard. Alternatively, when the available extraboard exceeds the amount of open work, surplus operators must be paid for services that customers never see. In either case, a cost is imposed, borne either by customers or the service provider.

Absences among operators occur for many reasons, and the incidence of some types of absence is more predictable than others. Generally, longer-duration absences are more predictable because they are oftentimes anticipated. Extended medical or disability leaves and retirements during the service period, for example, are sometimes known in advance, while those that are not can be reasonably determined from trend information. Also, the number of quits and terminations, though not known in advance, is fairly small and does not vary greatly. However, shorter-duration absences, extending from one to three days, are much more difficult to anticipate, and their variability accounts for much of the actual day-to-day surplus or deficit of extraboard requirements.

Both the general incidence and the variability of short-duration operator absences have increased since the implementation of the Family and Medical Leave Act (FMLA) of 1993. In a report on the responses received from its request for information on FMLA regulations, the U.S. Department of Labor (USDOL, 2007) identified the transit industry as being among the most affected by FMLA regulations on unscheduled intermittent leaves associated with serious medical conditions. FMLA regulations currently allow workers to notify their employer of such leaves up to two days after their occurrence. The USDOL report states that abuse of unscheduled intermittent leave privileges is widely perceived among employers, although employee organizations dispute claims that abuses are commonplace. In any event, frustrations over utilization of unscheduled intermittent leaves have reached a point where FMLA has been interpreted as the "Friday and Monday Leave Act" (Shopes, 2008).

Given the increasing frequency and daily volatility of short-duration absences, whether related to FMLA or other reasons, there is a need to gain a better understanding of their systematic occurrence in order to support extraboard planning efforts. The need for such analysis is underscored by a recent national survey that found all but one transit property relying on judgment and historic practice to support the extraboard planning process (DeAnnuntis and Morris, 2007). Apart from facilitating the planning process, improving our understanding of factors that contribute to short-duration absences may also help in 
identifying changes in policies or practices that would reduce their incidence. Beyond the direct interest in extraboard planning, research indicates that short-term absences presage more serious conditions, such as medical disabilities, and also lead to premature resignations (Kompier et al., 1990).

This report analyzes the incidence of short-duration absences among bus and light-rail operators at TriMet, the transit provider for the Portland, OR., metropolitan region. In contrast with earlier work, the analysis draws on an extensive array of operator-level information recovered by transit ITS technologies, including automatic vehicle location (AVL), automatic passenger counters (APCs), and event data recorders (EDRs). These systems have become widely deployed among mid-size and large transit agencies (Volpe Center, 2005), and their archived data have made important contributions to operations management and service planning (Furth et al., 2006), as well as to market research (Strathman et al., 2008).

In the present study, data from these technologies are combined with information from human resource, scheduling, incident, and customer relations databases to provide a comprehensive and detailed representation of operators' daily work environment. This approach also has the advantage of relying on arms-length data to assess work conditions that previous research, relying heavily on aggregate data and operator self-report surveys, has found to be important.

The remainder of this report is organized as follows: Findings from prior absence research are discussed in the next section. A model of short-duration absences that reflects both prior research and the data and information that are available in the present case is then specified. Empirical results of an absence model for bus and rail operators are then presented. The report concludes with a discussion of the implications of the findings for extraboard planning practice and for policies that would potentially reduce absences. 


\subsection{REVIEW OF PRIOR RESEARCH}

Despite nearly a century of scholarly attention - since absenteeism was first recognized as being distinct from labor turnover - a unified theory of absence behavior has not emerged. While research has brought to light many dimensions of absence behavior, progress has been mainly in broadening the field of study. Reviews of both theoretical (Fichman, 1984; Chadwick-Jones, Nicholson, \& Brown, 1982) and empirical (ChadwickJones et al., 1982; Farrell \& Stamm, 1988; Muchinski, 1977; Steers \& Rhodes, 1978; Steers \& Rhodes, 1984) absence research reveal a literature firmly in an exploratory mode. Reviewing over three decades of theoretical study, Fichman (1984: 4) succinctly described prior research efforts as "piecemeal."

\subsection{THEORETICAL FRAMEWORKS}

Most of the early theory-building research occurred in psychology and interpreted absenteeism as an avoidance behavior (Chadwick-Jones et al., 1982). In this framework, a dissatisfied employee who feels powerless to change her job role or work environment is motivated to withdraw. If such a worker chooses not to withdraw permanently by quitting the job, absenting herself more frequently from the job serves as a substitute behavior (Beehr \& Gupta, 1978). In this context, voluntary absence is interpreted as a response to job dissatisfaction (for reviews see Muchinski, 1977; Porter and Steers, 1973). In the avoidance framework, the greatest leverage in reducing absenteeism lies in improving worker satisfaction. However, the satisfaction-absence relationship has been strongly criticized on both empirical and theoretical grounds (e.g., Chadwick-Jones et al., 1982; Hackett \& Guion, 1985; Nicholson et al. 1976).

Although early examples exist (e.g., Stagner \& Rosen, 1965 cited in Hackett \& Guion, 1985 ), the notion that absence is the result of an economically rational decision process is a fairly recent development. A major theoretical advantage of this framework over the avoidance literature is the recognition that outside attractions, as well as job-related dissatisfaction, can motivate voluntary absenteeism. Allen (1981a) brought absence behavior into the neoclassical income-leisure model of labor supply. He outlined how workers would not usually find a job that employed them for the number of labor hours they desired. When a worker is contracted to work more hours than he prefers at a given wage rate, this implies that he would value additional leisure time more than wages lost by working less. When the penalties for missed work are not great, such a worker would improve his welfare by absenting himself from time to time.

Mismatches between desired and contracted hours are more likely to occur in group bargaining arrangements, since a standard number of hours worked is unlikely to correspond to individual preferences throughout a group (Allen, 1984). Allen (1981b) also extended absence theory to address unpleasant or hazardous job conditions. He 
concluded that workers would use periodic absence to compensate for difficult job conditions, and that employers might accept this rather than pay higher wages to induce better attendance.

In the work-leisure framework, absence is produced by an imbalance between the benefits and costs of missing work. Absence reduction would be most efficiently achieved by reducing the costs of attendance relative to the benefits. The present study includes extensive data on the daily working conditions faced by transit operators. This is the first time such data have been available to test the effect of a potentially important category of attendance costs.

While the avoidance and work-leisure decision frameworks operate almost exclusively at the individual level, the social exchange theory of absence expands the focus to include an employee's social context at work. In this framework, workers are viewed as members of a workplace culture, governed by a set of norms that define "acceptable" behavior among employees and between workers and management. Development of the social exchange absence framework occurred largely in Chadwick-Jones et al. (1982), building on initial work by Hill \& Trist (1953) that postulated an "absence culture" and related worker socialization process.

Within the social exchange framework there is a formal contract specifying terms of employment and there is also an informal social contract that specifies how much, and for what reasons, deviations from formal rules will be tolerated by peers and management. Chadwick-Jones et al. (1982) described the social contract constructed mainly through an ongoing negotiation between labor and management. In the context of an absence culture, the individual employee is neither strictly bound to official absence policy nor free to choose an attendance pattern he prefers. Instead, his absence choices depend on the prevailing acceptability of absence among his peers, itself determined through implicit acceptance by management. In this framework, the greatest potential to reduce absenteeism lies in renegotiating the implicit social contract between labor and management. The present study recognizes the potential importance of a socialization process for operators. Variables measuring career stage (seniority, full-time/part-time status), social subgroup (bus and rail modes, various garages and yards), and shift schedule are included to explore the possible role of a socialization process.

Three other frameworks have received less attention and are only briefly described here. First, the idea of absence as a habitual behavior reflects findings that past absence predicts future absence and that a small percentage of workers are responsible for a large percentage of absences. However, as Fichman (1984) noted, such findings are not sufficient to support the habit hypothesis without controlling for other important variables. Second, research suggests that absence may have little to do with job-related factors and instead may be driven by seemingly unrelated, external events. A recent study of transit operators lends support to this framework, finding that alcoholism and stressful life events are associated with increased absence frequency (Cunradi et al., 2005). Lastly, a functionalist framework contends that what is generally labeled "absence" actually encompasses a variety of distinct behaviors (Fichman, 1984). Thus it 
is important to carefully define the type of absence under study. This paper focuses on a particular type of absence (short duration) thought to be largely discretionary and perhaps motivated by similar functional considerations.

\subsection{EMPIRICAL FINDINGS}

A major obstacle in absence studies is defining and measuring absence itself. Muchinsky (1977: 321) referred to efforts up to the time of his survey as a "hodgepodge" and pointed to poor and inconsistent measurement as a key hindrance to empirical analysis. If different types (e.g., sickness, injury, excused, unexcused), durations (e.g., short-term and long-term), and measures (e.g., time-lost, frequency, rate) of absence reflect different underlying causes, a coherent understanding is unlikely to be attained where definitions are mixed and incompatible.

Steers \& Rhodes (1978) developed the most referenced framework for characterizing absence studies. Their framework is comprised of seven categories of factors potentially influencing work attendance with up to seven subcategories under each factor. This complex structure makes bivariate and correlational studies methodologically suspect and helps explain the inconsistent findings among early correlational studies (ChadwickJones et al., 1982; Steers and Rhodes, 1978; Muchinsky, 1977).

From 1980 onward, multivariate empirical studies have become more prevalent. This development owes much to the late arrival of the economics discipline in absence research. The number of multivariate analyses is fairly small, and model specifications do not show convergence toward an accepted set of explanatory variables. Table 1 lists the studies found in the present literature search, including details about data, absence types, and measures used. Numbered references in the following discussion refer to the list in the table.

A number of data limitations are clearly evident among the multivariate studies listed in the table. First, half of the studies relied on self-reported absences. Measurement error and response bias can be expected to affect the reliability of self-reported information. There is little incentive to reveal a poor attendance record, and recall of absences over a year-long period is unlikely to be very precise. Furthermore, the self-report data are also subject to sampling bias, since workers were generally not obligated to participate. Second, there is no consensus on absence measurement. Only Barmby et al. (1995) specified a daily attendance model, even though this would be the most appropriate model for the decision process framework that many of the studies employ. Five studies $(3,4,7,14,15)$ accounted for unobserved heterogeneity within the sample.

Based on process models in Kohler and Mathieu (1993) and Steers and Rhodes (1978), empirical findings can be divided into three categories: personal situational factors, work situational factors, and affective reactions to the combination of work and personal situations. Table 2 presents a selection of variables having a significant effect on absences in the selected multivariate empirical studies. 
Table 1: Key Features of Multivariate Absence Studies

\begin{tabular}{|c|c|c|c|}
\hline Author(s) & Date & Data & Absence Measure \\
\hline 1. Allen & $1981 a$ & $\begin{array}{l}\text { U.S. general population; self- } \\
\text { reported absences for previous two } \\
\text { weeks }\end{array}$ & $\begin{array}{l}\text { Absence rate (excluding paid } \\
\text { vacations and holidays) }\end{array}$ \\
\hline 2. Allen & $1981 b$ & $\begin{array}{l}\text { U.S. paper plant production workers, } \\
3.5 \text { years of monthly plant-level data }\end{array}$ & $\begin{array}{l}\text { Absence rate (< } 4 \text { days, excluding } \\
\text { vacations, holidays, layoffs; adjusted } \\
\text { for job-related illness and injuries) }\end{array}$ \\
\hline 3. Allen & 1984 & $\begin{array}{l}\text { U.S. general population; three self- } \\
\text { report surveys }\end{array}$ & $\begin{array}{l}\text { 1. Current week absence rate } \\
\text { 2. Two-week absence rate } \\
\text { 3. Absence frequency (5-point scale) }\end{array}$ \\
\hline 4. Barmby et al. & 1995 & $\begin{array}{l}\text { UK workers at two manufacturing } \\
\text { plants; daily records over } 2.5 \text { years }\end{array}$ & Absence for "unacceptable" reasons \\
\hline 5. Cunradi et al. & 2005 & $\begin{array}{l}\text { San Francisco MUNI operators, self- } \\
\text { reported absence over previous year }\end{array}$ & $\begin{array}{l}\text { "Miss-outs" (binary: "none" or "one } \\
\text { or more") }\end{array}$ \\
\hline $\begin{array}{l}\text { 6. Delgado \& } \\
\text { Kniesner }\end{array}$ & 1997 & $\begin{array}{l}\text { London bus operators and } \\
\text { conductors; daily records for one- } \\
\text { year period }\end{array}$ & $\begin{array}{l}\text { Count of absence spells with } \\
\text { durations of one week or less }\end{array}$ \\
\hline $\begin{array}{l}\text { 7. Dionne \& } \\
\text { Dostie }\end{array}$ & 2007 & $\begin{array}{l}\text { Canada general population, self- } \\
\text { reported absence over previous year }\end{array}$ & $\begin{array}{l}\text { Count of absences for workers who } \\
\text { missed less than } 50 \text { days }\end{array}$ \\
\hline $\begin{array}{l}\text { 8. Drago \& } \\
\text { Wooden }\end{array}$ & 1992 & $\begin{array}{l}\text { Australia/Canada/New Zealand/U.S.; } \\
\text { self-reported absences, paired } \\
\text { production facilities }\end{array}$ & $\begin{array}{l}\text { Absence rate (excluding officially } \\
\text { sanctioned leave) }\end{array}$ \\
\hline $\begin{array}{l}\text { 9. Dunn \& } \\
\text { Youngblood }\end{array}$ & 1986 & $\begin{array}{l}\text { Utility Co. union workers; survey and } \\
\text { admin. data over four years }\end{array}$ & $\begin{array}{l}\text { Time lost for unpaid unexcused and } \\
\text { unpaid requested time off }\end{array}$ \\
\hline $\begin{array}{l}\text { 10. Fitzgibbons } \\
\text { \& Moch }\end{array}$ & 1980 & $\begin{array}{l}\text { U.S. production workers; two } \\
\text { surveys, each covering one year and } \\
\text { admin. Data }\end{array}$ & $\begin{array}{l}\text { 1. Count of excused absences } \\
\text { 2. Count of sickness absences } \\
\text { 3. Count of unexcused absences }\end{array}$ \\
\hline 11. Keller & 1983 & $\begin{array}{l}\text { U.S. communication equipment } \\
\text { plant workers; two 10-month time } \\
\text { periods, admin. Data }\end{array}$ & Count of unexcused absences \\
\hline $\begin{array}{l}\text { 12. Kenyon \& } \\
\text { Dawkins }\end{array}$ & 1989 & $\begin{array}{l}\text { Australian national labor force; self- } \\
\text { reported absence, quarterly 1966-84 }\end{array}$ & $\begin{array}{l}\text { Percentage of full-time workers who } \\
\text { worked less than a full week at time } \\
\text { of survey }\end{array}$ \\
\hline 13. Leigh & 1980 & $\begin{array}{l}\text { U.S. Panel Study of Income } \\
\text { Dynamics; } 1977 \text { and } 1978 \text { self-report } \\
\text { surveys }\end{array}$ & $\begin{array}{l}\text { Hours absent (long-term and job- } \\
\text { related injury leaves adjusted out) }\end{array}$ \\
\hline 14. Leigh & 1985 & $\begin{array}{l}\text { U.S. Panel Study of Income } \\
\text { Dynamics; } 1973 \text { and } 1974 \text { self-report } \\
\text { surveys }\end{array}$ & $\begin{array}{l}\text { Two-year average of annual work- } \\
\text { hours lost due to illness }\end{array}$ \\
\hline $\begin{array}{l}\text { 15. Shiftan \& } \\
\text { Wilson }\end{array}$ & 2001 & $\begin{array}{l}\text { MBTA operators; weekly admin. data } \\
\text { covering one year }\end{array}$ & $\begin{array}{l}\text { Time lost: } \\
\text { 1. Short (voluntary and one-day sick) } \\
\text { 2. Long (two or more days sick) }\end{array}$ \\
\hline 16. Watson & 1981 & $\begin{array}{l}\text { Production workers from a small U.S. } \\
\text { metal fabrication plant; interview } \\
\text { and admin data over a 15-month } \\
\text { period }\end{array}$ & Count of days absent per month \\
\hline
\end{tabular}


Among personal situational factors, sex has garnered the clearest empirical support. Nine studies found a positive relationship between women and absence frequency. Allen (1981a) reported that this relationship does not necessarily hold among white-collar women and may even be negative in that context. At least three explanations have been given for higher absence incidence among blue-collar female workers (Fitzgibbons \& Moch, 1980). First, some women may place a higher value on non-work activities, decreasing the relative attractiveness of market work. Second, women may be located within different social structures in the workplace, with weaker attendance norms. Third, absence among women may be the result of a greater incidence of illness or injury. Fitzgibbons and Moch tested these alternatives and found evidence supporting the first and third but not the second.

Table 2: Effects of Selected Variables From Multivariate Absence Studies

\begin{tabular}{|c|c|c|}
\hline Variable & Positive Effect on Absence & Negative Effect on Absence \\
\hline \multicolumn{3}{|l|}{ Personal Situational Factors } \\
\hline Female & $1,3(1), 4,7,9,10(1), 11,13,14$ & \\
\hline Age & & $1,3(1), 6$ \\
\hline Married & $3(1), 7$ & $3(3), 11,16$ \\
\hline Family Size & 6 & $1,10(2,3)$ \\
\hline No. of Children & 9 & \\
\hline No. of Children*Female & 14 & \\
\hline Past Absence & $4,6,11$ & $15(1)$ \\
\hline \multicolumn{3}{|l|}{ Work Situational Factors } \\
\hline Wage & & $2,3(1), 4,6,7,9,12,13$ \\
\hline Overtime & & 12 \\
\hline Union & $1,3(1,3), 7,12,13,14$ & \\
\hline Seniority & 6,7 & $8,10(1,2,3), 11,14,15$ \\
\hline Full Time (or hrs. sched.) & $4,7,8,12$ & \\
\hline Tight Labor Market & $7,12,14$ & \\
\hline Shift Work & 7 & \\
\hline Evening Shift & $10(1)$ & \\
\hline Job Hazards & $1,2,14$ & \\
\hline Winter Quarter & 12 & \\
\hline Spring Quarter & 15 & \\
\hline Summer Quarter & 15 & 12 \\
\hline \multicolumn{3}{|l|}{ Affective Factors } \\
\hline Job Satisfaction & & $8,10(1,2)$ \\
\hline Health Problems & 1,14 & \\
\hline Burnout*Male & 5 & \\
\hline Male*Drinking & 5 & \\
\hline
\end{tabular}

* Numbers in the table refer to the studies listed in Table 1. Numbers in parentheses refer to the absence measure if more than one measure was used. Inclusion indicates significance at the $\alpha_{.05}$ level. 
Less extensive empirical support for a negative age-absence association in multivariate studies is somewhat surprising, given that age was one of the few consistent influences in simple correlation studies (Chadwick-Jones et al., 1982). Most multivariate studies found age to be inversely related to absence, but the effect was often not significant. Increasing age is thought to diminish the number and attractiveness of non-work activities and increase job commitment (Drago and Wooden, 1992). One explanation for the scant findings may lie in absence measures that often combined medical and disability leaves with more limited-duration absences.

Conflicting results for marriage and family-size effects are not surprising, since the presence of a spouse and other dependents exerts opposing pressures on work attendance. The wage benefits of working are likely to increase with family size. At the same time, the attraction of family time also would increase the costs of work attendance. Data on the presence or number of dependents are rarely available, but available results suggest that family-time pressures tend to dominate earning pressures when children are present, especially for female workers.

Past absence had a positive influence on present absence in three of the four studies that included this variable, consistent with the absence-as-habit framework. In the fourth study, Shiftan \& Wilson (2001) speculated that the negative relationship may have been due to workers who had already missed time wishing to avoid possible disciplinary action for further absence. Lacking past absence data, one way to pick up the effect of habit (and other missing variables with systematic effects) is by using fixed effects to control for unobserved heterogeneity at the individual or group level. Five of the multivariate studies $(3,4,7,14,15)$ used this technique.

Turning to work situational factors, the strongest empirical support has been for the inverse relationship between the wage rate and absence. The income-leisure decision framework is strongly supported by these results. Dunn and Youngblood (1986) performed a stricter test of the theory, specifying the gap between a worker's estimated marginal value of time and the wage rate. The inverse relationship held. Given the preponderance of evidence regarding wage rates, the paucity of significant findings for overtime hours indicates that some workers are self-selecting into overtime when they perceive smaller benefits from foregone non-work activities while others may not have that option.

Union membership had a consistently positive association with absence in the studies reviewed. This is consistent with an adjustment framework involving a distinct absence culture. However, it is difficult to ensure that work situations and compensation plans are similar when comparing studies of union and non-union employees. If union members receive higher proportions of fringe benefits, this would tend to increase absenteeism (Chelius, 1981). The same would be true if union jobs tend to coincide with unpleasant, hazardous working conditions (Allen, 1981b). 
While a majority of studies found a negative relationship between seniority and absence, two studies found a positive association. Increased absence with longer tenure is consistent with Cunradi et al.'s (2005) finding of absences linked to job "burnout." It may be important to control separately for the effects of decreased tolerance for tedious work on one hand and the positive effects of seniority, such as work assignment and shift preference, on the other, to accurately measure the absence-tenure relationship.

Full-time employees are more likely to be absent than part-time/reduced-hour workers, consistent with the decision-process framework. Where part-time workers include those desiring promotion to full time, the difference will be further reinforced. Alternatively, a tight external labor market provides more numerous alternatives to workers' current jobs, thereby lessening the consequences of termination or other sanctions for more frequent absences.

Rotating shift work (evening shifts in particular) was found to be positively related with absence. Fitzgibbons and Moch (1980) note that shift work has been understudied in the absence literature. They find support for the hypothesis that evening shifts (7-11 p.m.) are most likely to cause absence, since they conflict strongly with family time and other social activities.

Job hazards, in the limited cases where data are available, are consistently related with higher absenteeism. Allen (1981b) suggested that absence is implicitly offered as a fringe benefit in dangerous or stressful jobs to allow workers to better manage risks. This view is consistent with both the decision process and adjustment/socialization frameworks. Measures have been crude and most have been aggregate, categorical selfreport metrics. The present study includes both objective measures of individual exposure to job stressors, as well as third-party measures of operator stress and fatigue in the form of passenger comments.

Finally, while there are reasons to expect seasonality, only two of the multivariate studies tested for seasonal variation of absences. This is due almost entirely to data that were either too coarse or timeframes that were too brief to capture systematic variation across seasons. Both sickness patterns and non-work attractions would be expected to vary seasonally, and the present study includes seasonal variables to test for these effects.

Kohler and Mathieu (1993) found evidence that affective reactions are partly comprised of and also partially mediate personal and work situational factors in the absence process. As the sparse evidence reveals, affective reactions have not been a primary focus of multivariate absence studies. Affective reactions are "fuzzier" concepts, making measurement more costly and difficult.

Two studies $(8,10)$ found a negative relationship between job satisfaction and absence, consistent with the approach/avoidance framework. Two studies $(1,14)$ found a positive association between self-reported health problems and absence. Cunradi et al. (2005) reported positive coefficients on problem drinking and job burnout with regard to absence. The data employed in the present study are generally not well-suited to 
measuring affective reactions. However, customer comments - particularly with regard to the operator's condition and behavior - serve as rough proxies for operators' reactions to the work environment. Also, to the extent that affective reactions are stable over time (reflecting, for example, attitudes, values, and general satisfaction with work), fixed effects will account for covariance of affective reactions with absence.

Only one of the multivariate studies reviewed here was organized around daily attendance microdata. Barmby et al. (1995) used daily attendance data over a one-year period for 1,150 workers from two UK manufacturing plants. Determinants of daily attendance in their model included personal situational factors, employment status, and wages. They did not use data on work assignments - such as position type or shift schedule - beyond FT/PT status, nor was seasonality considered. Data on exposure to hazards and stressors at work were not available.

The present study considerably extends previous research on absence as a daily decision process. The objective measurement of the daily work assignment and conditions faced by operators is of considerable interest. Promising results have generally been found regarding job stress, work assignment and absenteeism, but past measures have been crude approximations.

\subsection{TRANSIT OPERATING ENVIRONMENT AND STRESS}

The transit industry is particularly suited to studying potential absence effects of the work environment. The operating environment that transit operators face is stressful and fatiguing, the negative health effects of which are well-documented (for reviews see Long and Perry, 1985; Winkleby et al., 1988). As Gardell et al. (1982, cited in Greiner et al., 1998) explained, operators are expected to drive safely, stay on schedule, and provide friendly customer service, even though these expectations are often in conflict. Stress reactions from such conflicts can contribute to short-term, voluntary absence as well as long-term illness (Gardell et al., 1982, cited in Long and Perry, 1985). Gardell et al. reported that traffic congestion, difficult passengers, and running behind schedule are associated with physiological stress reactions such as elevated blood pressure. Evans et al. (1999) further established the link between operating conditions and driver stress using a quasi-experimental before-and-after design in Stockholm. They found that bus operators whose routes were treated to reduce difficult situations (e.g., adding bus-only lanes, automating stop announcements, moving stops to curb-outs and eliminating difficult turns) showed significant declines in stress relative to operators on similar untreated routes.

Studies relating job-related stress directly with short-term absences to date are disappointing. Long and Perry (1985) reviewed several international studies that found transit operators were more likely than administrative workers to be absent for stressrelated psychosomatic illness. While the studies are consistent with the hypothesis that stressful working conditions increase absence, there are too many other potential differences between the comparison groups to draw meaningful conclusions. 
Greiner et al. (1998) observed San Francisco MUNI operators' working environments and manually coded three types of stress measures: time barriers (impediments and interruptions), break time, and schedule pressure. Operators in the highest of three time barrier groups were found to have a higher incidence of sickness absence after controlling for age, sex, tenure, and vehicle type. The two other stress measures were not significant. The broad definitions of each stressor category made interpretation difficult. For example, the time barrier category consisted of 31 unique codings, ranging from missed relief to unruly passengers to various vehicle malfunctions.

Cunradi et al. (2005) found that San Francisco MUNI operators who reported having had "miss outs" (last minute failures to report) in the past year also reported more frequent and severe stressors on the job. However, there is no way to distinguish whether operators with miss outs experienced different working conditions or merely were more affected by similar conditions. The current study overcomes some of the previous stressabsence study shortcomings by relating variations in operator absence to a set of objective measures of time pressure, passenger activity, and equipment problems. Shift time of day and shift type - also included in the present analysis - also may proxy for operating conditions, since certain shifts (AM and PM peak) face greater traffic volumes and passenger movements.

Lastly, management and labor do not generally agree on the contribution of operating conditions and work assignments to absence frequency. For example, in a survey of 36 transit agencies, managers did not identify stressful working conditions as being among the primary causes of operator absence (Volinski, 1999). Alternatively, in operator focus groups, tight schedules, malfunctioning equipment, and difficult or threatening passengers were cited as key reasons for needing to take a day off. These findings correspond with earlier operator surveys by Chadwick-Jones et al. (1982), which found UK public transit operators were more likely than other blue-collar workers to cite fatigue or just "wanting a break" from the job as key absence rationale. 



\subsection{DATA AND MODEL}

The data consist of the daily attendance records and the work performed by TriMet's 1,362 bus and 175 light-rail regular-duty operators in 2006 and 2007. The incidence of absences within the study timeframe is limited to durations of three days or less, and daily records associated with operators on medical, disability, or other more extended leaves are deleted. The operator absence model posits a daily attendance decision of the following general form:

$$
\begin{aligned}
& A_{i t}=f\left(\text { Personal }_{i t}, \text { Empl. Status }_{i t}, \text { Assigned Work }_{i t}\right. \text {, Service Deliveryit-30, Cust. } \\
& \text { Relations }_{\text {it-30), where }} \\
& \mathrm{A}_{\mathrm{it}} \quad=\text { Attendance or absence of operator } \mathrm{i} \text { on workday } \mathrm{t} \text {; } \\
& \text { Personal }_{i t} \quad=\text { A vector of operator i's personal characteristics on workday t; } \\
& \text { Empl. Status }_{i t}=\text { A vector of operator i's employment status characteristics on } \\
& \text { workday t; } \\
& \text { Assigned Work } \text { W }_{\mathrm{it}}=\text { A vector of operator i's assigned work characteristics on } \\
& \text { workday t; } \\
& \text { Service Delivery }{ }_{i t-30}=\text { A vector of operator i's service delivery characteristics during the } \\
& \text { 30-day period prior to workday t; } \\
& \text { Cust. Relations }_{\text {it }-30}=\text { A vector of customer commendations and complaints received } \\
& \text { referencing operator } \mathrm{i} \text { during the } 30 \text {-day period prior to } \\
& \text { workday t. }
\end{aligned}
$$

Definitions of the variables comprising the terms presented above are provided in an Appendix table, along with descriptive statistics. Personal characteristics include age, sex, and race or ethnicity. Employment status characteristics include seniority and fulltime, part-time, or probationary (initial six months) status. Assigned work characteristics include garage or yard, run type, run period, scheduled overtime, and route type. Also, assigned work characteristics include temporal variables such as year, month, day of the week, and whether the workday occurred on a holiday (qualifying for overtime pay) or on the day before or after the operator's regular day off.

Service delivery characteristics over the 30-day period prior to the workday include relative on-time performance, actual layover time, passenger boardings per revenue hour, and lift operations per revenue hour. Service delivery characteristics also include prior 30-day counts of pre-coded text messages sent by the operator to the dispatch center related to the following events or incidents: requests for security response; requests for vehicle trades or road calls; and incidents involving lost service, traffic delays, accidents/property damage, passenger slips/trips/falls, silent alarms, and taking evasive action. 
Lastly, the service delivery characteristics include counts of work-rule violations and incidents in which the operator's fitness for duty was examined. Customer comments over the 30-day period prior to the workday include complaints related to service delivery (most commonly associated with missed service, early departures, pass-ups, delays and breakdowns), unsafe operation of the vehicle, and rude or unprofessional treatment by the operator. Commendations are grouped into two categories: stop announcements and commendations for all other reasons.

In addition to these variables, operator-level fixed effects are specified. A fixed effect is specified for each full-time operator who completed more than 50 workday assignments over the two-year period. Fixed effects are thus coded for 778 bus and 113 light-rail operators. The fixed effects are included to capture the influence of omitted variables related to each of the identified operators. As suggested by the discussion in the previous section, the fixed effects may reflect influences such as absence-as-habit, job satisfaction, and non-work activity demands or opportunities.

The list of variables is more extensive for the bus-operator model. AVL technology has not been deployed on the light-rail system (although rail loop data are used to calculate on-time performance). Rail also lacks the event data recorders that recover the pre-coded text messages transmitted from buses. Also, all rail operators are full time. Lastly, the number of sample records is limited by incomplete data recovery and data validation processes. About $30 \%$ of the bus fleet is not equipped with APCs, eliminating their respective runs from the analysis. The data validation process results in the elimination of records for about $5 \%$ of runs. The number of valid "operator-day" records remaining for analysis thus totals 390,275 (bus operators) and 42,083 (light-rail operators), respectively. 


\subsection{EMPIRICAL RESULTS}

Linear probability estimates of the absence-decision parameters for bus and rail operators are presented in Table 3. Parameter estimates are provided for models with and without operator fixed effects. The parameter estimates are directly interpretable as a change in the marginal probability of an absence given a unit change in the selected variable. Given the number of variables covered in the models, the discussion is limited to parameter estimates for bus operators, focusing first on results without operator fixed effects. The impacts resulting from adding the operator fixed effect terms are then discussed.

\subsection{PERSONAL CHARACTERISTICS AND EMPLOYMENT STATUS}

The likelihood of an absence is estimated to decrease at a diminishing rate with respect to operator age, reaching a minimum well beyond the upper age limit within the sample. In contrast, absences are estimated to increase at a diminishing rate with respect to experience, reaching a maximum at 15 years. Considered jointly, the declines in absence likelihood associated with age more than offset the increases associated with experience. Combining the estimated effects of age and experience, these results indicate that the absence rate for a 40-year-old operator with 15 years experience would be .5 percentage points lower than a 30-year-old operator with 5 years experience. For a 60 -year-old operator with 35 years experience, the estimated gap would grow to 3.9 percentage points.

Regarding race and ethnicity, African-American, Asian, and Hispanic operators are estimated to have progressively smaller absence likelihoods than Caucasian operators. The absence likelihood of female operators is estimated to be about 3.9 percentage points higher than male operators. Part-time operators' absence likelihood is estimated to be over two percentage points lower than full-time operators. The estimated gap between full- and part-time status is thus much greater for females than it is for males, which is a reflection of the challenges that women face in balancing work and non-work responsibilities, as discussed earlier and observed elsewhere by Gramm (1975) and Gronau (1977). Operators are first hired on part-time status and serve an initial sixmonth probationary period. The estimated absence likelihood for a probationary parttime operator is over 3.6 percentage points below the estimated full-time operator rate.

\subsection{ASSIGNED WORK}

Bus operators' work is assigned out of three facilities, with Center Street serving as the primary garage, and Powell and Merlo serving as satellite facilities. During the two-year study period, the estimated absence likelihood for operators dispatched from the Powell

garage was estimated to be .3 percentage points lower than those dispatched from Center, 
while the likelihood among operators dispatched from the Merlo garage was estimated to be more than .9 percentage points higher. 
Table 3: Operator Absence Model Parameter Estimates (t-values in parentheses)

\begin{tabular}{|c|c|c|c|c|}
\hline \multirow[b]{2}{*}{ Variable } & \multicolumn{2}{|c|}{ Bus Operators } & \multicolumn{2}{|c|}{ Rail Operators } \\
\hline & $\begin{array}{l}\text { Without Fixed } \\
\text { Effects }\end{array}$ & With Fixed Effects & $\begin{array}{l}\text { Without Fixed } \\
\text { Effects }\end{array}$ & With Fixed Effects \\
\hline \multicolumn{5}{|c|}{ Personal Characteristics } \\
\hline Age & $\begin{array}{l}-.0017 \\
(-5.14)\end{array}$ & $\begin{array}{l}-.0024 \\
(-4.85)\end{array}$ & $\begin{array}{l}.0052 \\
(3.68)\end{array}$ & $\begin{array}{c}-.0010 \\
(-.27)\end{array}$ \\
\hline $\mathrm{Age}^{2}$ & $\begin{array}{l}.00001 \\
(2.45)\end{array}$ & $\begin{array}{c}.00002 \\
(3.39)\end{array}$ & $\begin{array}{c}-.00006 \\
(-4.40)\end{array}$ & $\begin{array}{c}-.000005 \\
(-.12)\end{array}$ \\
\hline Male & -- & -- & -- & -- \\
\hline Female & $\begin{array}{c}.0394 \\
(42.21)\end{array}$ & $\begin{array}{l}.0369 \\
(9.42)\end{array}$ & $\begin{array}{c}.0343 \\
(13.34)\end{array}$ & $\begin{array}{l}.0252 \\
(3.21)\end{array}$ \\
\hline Caucasian & -- & -- & -- & -- \\
\hline African-American & $\begin{array}{l}-.0047 \\
(-4.48) \\
\end{array}$ & $\begin{array}{l}.0071 \\
(3.21) \\
\end{array}$ & $\begin{array}{l}.0407 \\
(8.67) \\
\end{array}$ & $\begin{array}{l}-.0788 \\
(-1.89) \\
\end{array}$ \\
\hline Asian & $\begin{array}{l}-.0135 \\
(-7.19) \\
\end{array}$ & $\begin{array}{l}-.0098 \\
(-2.84) \\
\end{array}$ & $\begin{array}{l}.0294 \\
(4.93) \\
\end{array}$ & $\begin{array}{l}-.0304 \\
(-2.67) \\
\end{array}$ \\
\hline Hispanic & $\begin{array}{c}-.0200 \\
(-10.39) \\
\end{array}$ & $\begin{array}{l}-.0112 \\
(-3.02) \\
\end{array}$ & $\begin{array}{c}-.0004 \\
(-.07) \\
\end{array}$ & $\begin{array}{l}-.0207 \\
(-1.64) \\
\end{array}$ \\
\hline Years Experience & $\begin{array}{l}.0015 \\
(7.88) \\
\end{array}$ & $\begin{array}{c}.0054 \\
(15.49) \\
\end{array}$ & $\begin{array}{l}.0040 \\
(4.05) \\
\end{array}$ & $\begin{array}{c}-.0012 \\
(-.45) \\
\end{array}$ \\
\hline Years Experience $^{2}$ & $\begin{array}{c}-.00005 \\
(-8.68) \\
\end{array}$ & $\begin{array}{c}-.0002 \\
(-13.32) \\
\end{array}$ & $\begin{array}{c}-.00014 \\
(-4.58) \\
\end{array}$ & $\begin{array}{c}.00001 \\
(.14) \\
\end{array}$ \\
\hline Regular Full Time & -- & -- & -- & -- \\
\hline Part Time & $\begin{array}{c}-0217 \\
(-11.01) \\
\end{array}$ & $\begin{array}{c}-.0363 \\
(-11.78) \\
\end{array}$ & -- & -- \\
\hline Part Time * Female & $\begin{array}{c}-0257 \\
(-16.12) \\
\end{array}$ & $\begin{array}{l}-.0248 \\
(-6.28) \\
\end{array}$ & -- & -- \\
\hline Probationary & $\begin{array}{l}-.0148 \\
(-7.19)\end{array}$ & $\begin{array}{l}-.0063 \\
(-2.88)\end{array}$ & -- & -- \\
\hline
\end{tabular}




\begin{tabular}{|c|c|c|c|c|}
\hline Assigned Work Characteristics & & & & \\
\hline Center Garage & -- & -- & -- & -- \\
\hline Powell Garage & $\begin{array}{l}.0031 \\
(-3.54)\end{array}$ & $\begin{array}{l}.0048 \\
(-3.89)\end{array}$ & -- & -- \\
\hline Merlo Garage & $\begin{array}{l}.0095 \\
(9.33) \\
\end{array}$ & $\begin{array}{l}-.0025 \\
(-1.69) \\
\end{array}$ & -- & -- \\
\hline Ruby Junction Yard & -- & -- & -- & -- \\
\hline Elmonica Yard & -- & -- & $\begin{array}{l}.0065 \\
(2.86)\end{array}$ & $\begin{array}{l}-.0045 \\
(-1.02)\end{array}$ \\
\hline Straight Run & -- & -- & -- & -- \\
\hline Regular Relief & $\begin{array}{l}-.0025 \\
(-2.34)\end{array}$ & $\begin{array}{l}-.0017 \\
(-1.29)\end{array}$ & $\begin{array}{l}-.0065 \\
(-2.42)\end{array}$ & $\begin{array}{c}-.0018 \\
(-.58)\end{array}$ \\
\hline Vacation Relief & $\begin{array}{l}.0056 \\
(3.07)\end{array}$ & $\begin{array}{l}.0081 \\
(3.35)\end{array}$ & $\begin{array}{l}.0138 \\
(2.36)\end{array}$ & $\begin{array}{l}.0189 \\
(2.76)\end{array}$ \\
\hline Full-Time Split & $\begin{array}{c}.0214 \\
(15.14)\end{array}$ & $\begin{array}{c}.0204 \\
(12.76)\end{array}$ & $\begin{array}{l}.0192 \\
(4.69)\end{array}$ & $\begin{array}{l}.0290 \\
(6.37)\end{array}$ \\
\hline Part-Time Split & $\begin{array}{c}.0180 \\
(10.75)\end{array}$ & $\begin{array}{c}.0244 \\
(13.92)\end{array}$ & - & -- \\
\hline PM Run (ends between 4:30 and 11p.m.) & -- & -- & -- & -- \\
\hline Day Run (ends before 4:30 p.m.) & $\begin{array}{l}-.0076 \\
(-6.89)\end{array}$ & $\begin{array}{l}-.0082 \\
(-5.90)\end{array}$ & $\begin{array}{l}-.0132 \\
(-3.96)\end{array}$ & $\begin{array}{c}-.0037 \\
(-.94)\end{array}$ \\
\hline Night Run (ends after 11 p.m.) & $\begin{array}{l}-.0027 \\
(-2.24)\end{array}$ & $\begin{array}{c}-.0008 \\
(-.57)\end{array}$ & $\begin{array}{l}-.0177 \\
(-5.13)\end{array}$ & $\begin{array}{l}-0071 \\
(-1.75)\end{array}$ \\
\hline Scheduled Overtime (hours, prior month) & $\begin{array}{l}.0003 \\
(3.31)\end{array}$ & $\begin{array}{c}.00001 \\
(.12)\end{array}$ & $\begin{array}{c}-.0002 \\
(-.77)\end{array}$ & $\begin{array}{c}-.0002 \\
(-.64)\end{array}$ \\
\hline Scheduled Overtime $^{2}$ & $\begin{array}{c}-.000008 \\
(-5.39)\end{array}$ & $\begin{array}{c}.000001 \\
(.65)\end{array}$ & $\begin{array}{c}-.000002 \\
(-.46)\end{array}$ & $\begin{array}{c}.000003 \\
(.74)\end{array}$ \\
\hline Trunk Radial (frequent service) & -- & -- & -- & -- \\
\hline Trunk Radial (secondary) & $\begin{array}{l}-.0014 \\
(-1.79)\end{array}$ & $\begin{array}{l}.0009 \\
(1.11)\end{array}$ & -- & -- \\
\hline Crosstown & $\begin{array}{l}-.0042 \\
(-5.33)\end{array}$ & $\begin{array}{c}-.00004 \\
(.00)\end{array}$ & -- & -- \\
\hline Feeder & $\begin{array}{l}-.0035 \\
(-4.24)\end{array}$ & $\begin{array}{l}-.0022 \\
(-2.50)\end{array}$ & -- & -- \\
\hline Peak Express & -.0040 & -.0005 & -- & -- \\
\hline
\end{tabular}




\begin{tabular}{|c|c|c|c|c|}
\hline & $(-3.49)$ & $(-.45)$ & & \\
\hline \multicolumn{5}{|c|}{ Temporal Characteristics } \\
\hline 2006 & -- & -- & -- & -- \\
\hline 2007 & $\begin{array}{l}.0026 \\
(3.66)\end{array}$ & $\begin{array}{l}.0030 \\
(4.10)\end{array}$ & $\begin{array}{l}-.0087 \\
(-3.91)\end{array}$ & $\begin{array}{l}-.0068 \\
(-2.82)\end{array}$ \\
\hline January & -- & -- & -- & -- \\
\hline February & $\begin{array}{l}-.0039 \\
(-2.32)\end{array}$ & $\begin{array}{l}-.0028 \\
(-1.69)\end{array}$ & $\begin{array}{c}-.0048 \\
(-.94)\end{array}$ & $\begin{array}{c}-.0025 \\
(-.50)\end{array}$ \\
\hline March & $\begin{array}{c}-0092 \\
(-5.58) \\
\end{array}$ & $\begin{array}{l}.0079 \\
(-4.81)\end{array}$ & $\begin{array}{l}-.0108 \\
(-2.16)\end{array}$ & $\begin{array}{l}-.0070 \\
(-1.40)\end{array}$ \\
\hline April & $\begin{array}{l}-0146 \\
(-8.66) \\
\end{array}$ & $\begin{array}{l}-0118 \\
(-7.05) \\
\end{array}$ & $\begin{array}{l}-.0165 \\
(-3.23)\end{array}$ & $\begin{array}{l}-.0118 \\
(-2.32)\end{array}$ \\
\hline May & $\begin{array}{r}-.0141 \\
(-8.37) \\
\end{array}$ & $\begin{array}{l}-.0123 \\
(-7.35) \\
\end{array}$ & $\begin{array}{r}-.0150 \\
(-2.92) \\
\end{array}$ & $\begin{array}{r}-.0116 \\
(-2.25) \\
\end{array}$ \\
\hline June & $\begin{array}{l}-.0105 \\
(-6.31) \\
\end{array}$ & $\begin{array}{l}-.0092 \\
(-5.60) \\
\end{array}$ & $\begin{array}{c}-.0041 \\
(-.79) \\
\end{array}$ & $\begin{array}{c}-.0021 \\
(-.40) \\
\end{array}$ \\
\hline July & $\begin{array}{r}-.0159 \\
(-9.38) \\
\end{array}$ & $\begin{array}{r}-.0139 \\
(-8.33) \\
\end{array}$ & $\begin{array}{l}-.0155 \\
(-2.89) \\
\end{array}$ & $\begin{array}{r}-.0127 \\
(-2.36) \\
\end{array}$ \\
\hline August & $\begin{array}{l}-.0099 \\
(-5.87)\end{array}$ & $\begin{array}{l}.0080 \\
(-4.78) \\
\end{array}$ & $\begin{array}{l}-.0165 \\
(-3.08) \\
\end{array}$ & $\begin{array}{l}-0120 \\
(-2.22) \\
\end{array}$ \\
\hline September & $\begin{array}{l}-.0117 \\
(-6.83) \\
\end{array}$ & $\begin{array}{l}-.0104 \\
(-6.14)\end{array}$ & $\begin{array}{l}-.0191 \\
(-3.74) \\
\end{array}$ & $\begin{array}{r}-.0167 \\
(-3.26) \\
\end{array}$ \\
\hline October & $\begin{array}{l}-.0081 \\
(-4.82) \\
\end{array}$ & $\begin{array}{l}-.0069 \\
(-4.13) \\
\end{array}$ & $\begin{array}{r}-.0118 \\
(-2.34) \\
\end{array}$ & $\begin{array}{r}-.0091 \\
(-1.79) \\
\end{array}$ \\
\hline November & $\begin{array}{l}-.0066 \\
(-3.90)\end{array}$ & $\begin{array}{l}-.0054 \\
(-3.24)\end{array}$ & $\begin{array}{l}-.0132 \\
(-2.57)\end{array}$ & $\begin{array}{l}-.0080 \\
(-1.55)\end{array}$ \\
\hline December & $\begin{array}{l}-.0054 \\
(-2.59)\end{array}$ & $\begin{array}{l}-.0048 \\
(-2.31)\end{array}$ & $\begin{array}{l}-.0179 \\
(-2.84)\end{array}$ & $\begin{array}{l}-.0121 \\
(-1.91)\end{array}$ \\
\hline Monday & $\begin{array}{c}.0012 \\
(.94)\end{array}$ & $\begin{array}{c}.0004 \\
(.33)\end{array}$ & $\begin{array}{l}.0006 \\
(.16)\end{array}$ & $\begin{array}{c}-.00008 \\
(-.02)\end{array}$ \\
\hline Tuesday & -- & -- & -- & -- \\
\hline Wednesday & $\begin{array}{l}.0017 \\
(1.43)\end{array}$ & $\begin{array}{l}.0007 \\
(.59)\end{array}$ & $\begin{array}{l}.0013 \\
(.34)\end{array}$ & $\begin{array}{l}.0003 \\
(.08)\end{array}$ \\
\hline Thursday & $\begin{array}{l}.0071 \\
(5.95) \\
\end{array}$ & $\begin{array}{l}.0048 \\
(4.03)\end{array}$ & $\begin{array}{l}.0116 \\
(3.04)\end{array}$ & $\begin{array}{l}.0114 \\
(2.97)\end{array}$ \\
\hline Friday & .0076 & .0056 & .0077 & .0088 \\
\hline
\end{tabular}




\begin{tabular}{|c|c|c|c|c|}
\hline & (5.79) & $(4.32)$ & $(1.96)$ & $(2.25)$ \\
\hline Saturday & $\begin{array}{l}.0081 \\
(5.26)\end{array}$ & $\begin{array}{l}.0081 \\
(5.26)\end{array}$ & $\begin{array}{c}-.0036 \\
(-.86)\end{array}$ & $\begin{array}{l}-.0016 \\
(-.39)\end{array}$ \\
\hline Sunday & $\begin{array}{l}.0031 \\
(1.86)\end{array}$ & $\begin{array}{l}.0029 \\
(1.78)\end{array}$ & $\begin{array}{l}.0136 \\
(3.15)\end{array}$ & $\begin{array}{l}.0134 \\
(3.07)\end{array}$ \\
\hline Holiday & $\begin{array}{l}-.0115 \\
(-3.55)\end{array}$ & $\begin{array}{l}-.0104 \\
(-3.26)\end{array}$ & $\begin{array}{l}-.0113 \\
(-1.34)\end{array}$ & $\begin{array}{l}-.0071 \\
(-.85)\end{array}$ \\
\hline Day Before Regular Day Off & $\begin{array}{c}.0151 \\
(15.46)\end{array}$ & $\begin{array}{c}.0152 \\
(15.84)\end{array}$ & $\begin{array}{l}.0170 \\
(6.27)\end{array}$ & $\begin{array}{l}.0164 \\
(6.09)\end{array}$ \\
\hline Day After Regular Day Off & $\begin{array}{l}.0042 \\
(4.25)\end{array}$ & $\begin{array}{l}.0044 \\
(4.43)\end{array}$ & $\begin{array}{l}.0038 \\
(1.42)\end{array}$ & $\begin{array}{l}.0032 \\
(1.20)\end{array}$ \\
\hline \multicolumn{5}{|l|}{ Service Delivery Characteristics } \\
\hline $\begin{array}{l}\text { Prior Month On-Time Departures (v. peers, } \\
\text { proportionate difference) }\end{array}$ & -- & -- & -- & -- \\
\hline $\begin{array}{l}\text { Prior Month Early Departures (v. peers, } \\
\text { proportionate difference) }\end{array}$ & $\begin{array}{l}.0464 \\
(5.80) \\
\end{array}$ & $\begin{array}{l}.0227 \\
(2.34) \\
\end{array}$ & $\begin{array}{l}.1317 \\
(3.76) \\
\end{array}$ & $\begin{array}{l}.0360 \\
(.84)\end{array}$ \\
\hline $\begin{array}{l}\text { Prior Month Late Departures (v. peers, } \\
\text { proportionate difference) }\end{array}$ & $\begin{array}{l}.0585 \\
(9.76)\end{array}$ & $\begin{array}{l}.0415 \\
(6.51)\end{array}$ & $\begin{array}{r}-.0247 \\
(-.84)\end{array}$ & $\begin{array}{c}-.0094 \\
(-.29)\end{array}$ \\
\hline $\begin{array}{l}\text { Prior Month Average Speed (v. peers, } \\
\text { difference) }\end{array}$ & $\begin{array}{l}.0016 \\
(6.95) \\
\end{array}$ & $\begin{array}{l}.0005 \\
(1.88) \\
\end{array}$ & -- & -- \\
\hline $\begin{array}{l}\text { Actual Layover Time (proportion of } \\
\text { revenue hours, prior month) }\end{array}$ & $\begin{array}{l}.0030 \\
(.38)\end{array}$ & $\begin{array}{l}.0093 \\
(1.11)\end{array}$ & $\begin{array}{l}-.0771 \\
(-3.04)\end{array}$ & $\begin{array}{l}-.0774 \\
(-2.44)\end{array}$ \\
\hline Boardings Per Revenue Hour (prior month) & $\begin{array}{l}.0001 \\
(2.67)\end{array}$ & $\begin{array}{l}.0003 \\
(4.70)\end{array}$ & -- & -- \\
\hline Lifts Per Revenue Hour (prior month) & $\begin{array}{l}.0206 \\
(2.77)\end{array}$ & $\begin{array}{l}.0124 \\
(1.62)\end{array}$ & -- & -- \\
\hline Lifts Per Revenue Hour ${ }^{2}$ (prior month) & $\begin{array}{l}-.0323 \\
(-2.71)\end{array}$ & $\begin{array}{l}-.0245 \\
(-2.04)\end{array}$ & -- & -- \\
\hline Security-Response Requests (prior month) & $\begin{array}{c}.0076 \\
(10.46)\end{array}$ & $\begin{array}{l}.0020 \\
(2.57)\end{array}$ & -- & -- \\
\hline Road-Trade Requests (prior month) & $\begin{array}{l}.0037 \\
(7.11)\end{array}$ & $\begin{array}{l}.0008 \\
(1.49)\end{array}$ & -- & -- \\
\hline Lost-Service Incidents (prior month) & $\begin{array}{l}.0028 \\
(6.13)\end{array}$ & $\begin{array}{l}.0007 \\
(1.54)\end{array}$ & -- & -- \\
\hline
\end{tabular}




\begin{tabular}{|c|c|c|c|c|}
\hline Road-Call Incidents (prior month) & $\begin{array}{l}.0023 \\
(3.72)\end{array}$ & $\begin{array}{l}.0008 \\
(1.23)\end{array}$ & -- & -- \\
\hline Traffic-Delay Incidents (prior month) & $\begin{array}{l}.0007 \\
(.73)\end{array}$ & $\begin{array}{l}.0003 \\
(.30)\end{array}$ & -- & -- \\
\hline $\begin{array}{l}\text { Accidents/Incidents Witnessed (prior } \\
\text { month) }\end{array}$ & $\begin{array}{l}.0049 \\
(2.43) \\
\end{array}$ & $\begin{array}{c}.0007 \\
(.35) \\
\end{array}$ & -- & -- \\
\hline $\begin{array}{l}\text { Passenger Slip, Trip \& Fall Incidents (prior } \\
\text { month) }\end{array}$ & $\begin{array}{l}.0025 \\
(1.31) \\
\end{array}$ & $\begin{array}{c}.00004 \\
(.02) \\
\end{array}$ & $\begin{array}{c}-.0006 \\
(-.12) \\
\end{array}$ & $\begin{array}{l}-.0008 \\
(-.17) \\
\end{array}$ \\
\hline Accidents (prior month) & $\begin{array}{l}.0018 \\
(1.49) \\
\end{array}$ & $\begin{array}{l}.0008 \\
(.63) \\
\end{array}$ & $\begin{array}{l}.0134 \\
(2.50) \\
\end{array}$ & $\begin{array}{l}.0119 \\
(2.21) \\
\end{array}$ \\
\hline $\begin{array}{l}\text { Incidents Requiring Evasive Action (prior } \\
\text { month) }\end{array}$ & $\begin{array}{l}.0067 \\
(1.97) \\
\end{array}$ & $\begin{array}{l}.0050 \\
(1.47) \\
\end{array}$ & $\begin{array}{l}.0006 \\
(.24) \\
\end{array}$ & $\begin{aligned}-.0006 \\
(-.25) \\
\end{aligned}$ \\
\hline Vandalism Incidents (prior month) & $\begin{array}{l}.0081 \\
(.93)\end{array}$ & $\begin{array}{l}.0047 \\
(.54) \\
\end{array}$ & -- & -- \\
\hline Silent-Alarm Incidents (prior month) & $\begin{array}{r}-.0027 \\
(-.87) \\
\end{array}$ & $\begin{array}{l}.0003 \\
(.09)\end{array}$ & -- & -- \\
\hline Work-Rule Violations (prior month) & $\begin{array}{l}.0073 \\
(.87) \\
\end{array}$ & $\begin{array}{l}.0010 \\
(.12) \\
\end{array}$ & $\begin{array}{ll}.0027 \\
(.73) \\
\end{array}$ & $\begin{array}{l}.0016 \\
(.43)\end{array}$ \\
\hline Property-Damage Incidents (prior month) & $\begin{array}{c}-.0005 \\
(-.12) \\
\end{array}$ & $\begin{array}{c}-.0038 \\
(-.85) \\
\end{array}$ & -- & -- \\
\hline “Fit-for-Duty" Incidents (prior month) & $\begin{array}{l}.0151 \\
(2.29) \\
\end{array}$ & $\begin{array}{l}.0166 \\
(2.52) \\
\end{array}$ & $\begin{array}{l}-.0020 \\
(-.45) \\
\end{array}$ & $\begin{aligned}-.0009 \\
(-.20) \\
\end{aligned}$ \\
\hline \multicolumn{5}{|l|}{ Customer Relations } \\
\hline Complaints: Public Relations (prior month) & $\begin{array}{l}.0037 \\
(4.83) \\
\end{array}$ & $\begin{array}{l}.0022 \\
(2.77) \\
\end{array}$ & -- & -- \\
\hline $\begin{array}{l}\text { Complaints: Unsafe Operation (prior } \\
\text { month) }\end{array}$ & $\begin{array}{l}.0044 \\
(3.61) \\
\end{array}$ & $\begin{array}{l}.0027 \\
(2.20) \\
\end{array}$ & $\begin{array}{l}-.0280 \\
(-2.51) \\
\end{array}$ & $\begin{array}{l}-.0196 \\
(-1.74) \\
\end{array}$ \\
\hline $\begin{array}{l}\text { Complaints: Service Delivery (prior } \\
\text { month) }\end{array}$ & $\begin{array}{l}.0041 \\
(2.74) \\
\end{array}$ & $\begin{array}{l}.0025 \\
(1.70) \\
\end{array}$ & $\begin{array}{l}.0199 \\
(1.63) \\
\end{array}$ & $\begin{array}{l}.0172 \\
(1.38) \\
\end{array}$ \\
\hline $\begin{array}{l}\text { Commendations: Stop Announcements } \\
\text { (prior month) }\end{array}$ & $\begin{array}{l}-.0015 \\
(-2.54) \\
\end{array}$ & $\begin{array}{c}-.00002 \\
(-.03)\end{array}$ & -- & -- \\
\hline Commendations: All Other (prior month) & $\begin{array}{l}.0018 \\
(2.14) \\
\end{array}$ & $\begin{array}{c}-.0004 \\
(-.44) \\
\end{array}$ & $\begin{array}{l}.0031 \\
(.63) \\
\end{array}$ & $\begin{aligned}-.0024 \\
(-.48) \\
\end{aligned}$ \\
\hline Intercept & $\begin{array}{c}.0984 \\
(11.38)\end{array}$ & $\begin{array}{l}.0964 \\
(7.88)\end{array}$ & $\begin{array}{l}-.0521 \\
(-1.47) \\
\end{array}$ & $\begin{array}{l}.1462 \\
(1.63)\end{array}$ \\
\hline
\end{tabular}




\begin{tabular}{|l|c|c|c|c|}
\hline & & & & \\
\hline Adjusted $\mathrm{R}^{2}$ & .02 & .06 & .02 & .04 \\
\hline Sample Size (Operator-Days) & 390,275 & 390,275 & 42,083 & 42,083 \\
\hline Number of Operators & 1,362 & 1,362 & 175 & 175 \\
\hline Number of Fixed Effect Operators & & 778 & & 113 \\
\hline
\end{tabular}


Straight runs are generally the most sought-after assignments among operators, while split assignments, whether full- or part-time, are the least desired. These preferences are reflected in the associated absence likelihood differentials across run types. Absence likelihoods for split runs are estimated to be about two percentage points higher than regular straight runs. This substantial differential corresponds to research indicating that splits contribute to greater fatigue as well as greater disruptions of operators' activities and relationships outside the workplace (Tse et al., 2006). Absence likelihoods among operators who sign on to replace operators who are on vacation are also estimated to be higher, while the estimated likelihood among those who sign on to cover work during other operators' regular days off is slightly lower.

With respect to time-of-day, the most desired assignments are those that correspond to normal business hours, while the least desired are those in which operators have to deal with the evening commuting rush at the end of their shift. These considerations are reflected in the negative estimated differentials for day and night runs.

Overtime hours are being increasingly built into the runs of full-time operators, reflecting efforts to contain fringe benefit costs as well as deal with limitations in the labor agreement on the use of part-time operators. Further examination of the signup process, within which work is selected by operators on the basis of seniority, revealed a clear preference for overtime hours. The runs selected by the most senior operators were generally straights containing the largest amounts of scheduled overtime, while those selected by operators with the least seniority were more comprised of splits and had fewer overtime hours. However desirable, absence likelihoods are estimated to increase at a decreasing rate with respect to scheduled overtime, reaching a maximum at 18.75 overtime hours per month. This maximum is fairly close to the sample mean scheduled overtime.

Turning to route typology, operators on radial routes with 15-minute or better service frequency to the CBD face more serious overload consequences from headway deviations, as well as greater interference from downtown traffic and construction activity. Thus, alternative route types, including secondary radials, feeders, peak expresses, and crosstowns are estimated to experience progressively lower estimated absence likelihoods.

\subsection{TEMPORAL CHARACTERISTICS}

Absence likelihoods were estimated to vary systematically with respect to temporal variables. At the annual scale, the absence likelihood in 2007 was estimated to be greater than in 2006. Seasonality also is evident, with a peak occurring during winter months and a trough occurring during summer months. Over the course of the week, absence likelihoods are lowest on Tuesdays and progressively increase through Thursdays, Fridays, and Saturdays. The absence likelihood also is estimated to increase 1.5 percentage points on the day before an operator's regular day off and by about .4 percentage points on the day following a regular day off. Absence likelihoods on holidays, which pay time-and-a-half, are estimated to be 1.2 percentage points lower. 


\subsection{SERVICE DELIVERY CHARACTERISTICS}

The practice of schedule writing has been greatly facilitated with the availability of AVLgenerated vehicle running time data. Schedules can now be developed for "typical" operators on a route, with recovery time added to account for random events.

Nevertheless, even with a "good" schedule, the largest share of running time variation on a route is attributable to differences in the driving habits of individual operators (Strathman et al., 2002). When operators depart from time points consistently late compared to their peers serving the same route during the same time period, the resulting stress is manifested in a greater absence likelihood. The absence likelihood of operators who depart late $25 \%$ more often than their peers is estimated to increase by nearly 1.5 percentage points.

Early departures, alternatively, are entirely avoidable. Operators who consistently leave early relative to their peers may be motivated by several objectives. First, early departures can pad the amount of layover time at the end of the route. Second, early departures diminish actual headways, allowing operators to carry lighter passenger loads. Control heads in the buses display schedule status in real time. Early departures are thus the result of voluntary actions. The absence likelihood of operators who depart early $25 \%$ more often to their peers is estimated to increase by nearly 1.2 percentage points.

Speeding relative to one's peers represents a potential safety threat. Speeding can occur as a consequence of stretching one's layover time, departing from the route origin late, and then "highballing it" to get back on schedule. The absence likelihood of operators whose average speed is $25 \%$ greater than their peers is estimated to increase by a very small amount (about .05 percentage points).

The volume of passenger movements reflects several considerations that may influence operators' absence likelihoods. First, in terms of exposure, a larger flow of passengers increases the prospect that an unpleasant encounter will occur. Second, a larger flow of passengers also means that crowding is more likely and that pass-ups will occur. In either event, additional stress is introduced into the operator's work environment. The absence likelihood of an operator whose boardings per hour are $25 \%$ greater than average is estimated to increase by nearly .1 percentage point.

Lift operations add 1-2 minutes to dwell times. When lift operations occur with regularity, time can be added to the schedule to account for longer dwells. When lift operations occur infrequently, schedules are not adjusted and delays from lift-extended dwells must be recovered. The effect of lift operations on operators' estimated absence likelihoods reaches a maximum at .5 lift events per hour, at which point the absence likelihood is estimated to increase by about .2 percentage points.

Operators can send preprogrammed messages to dispatchers by touching numbered buttons on the vehicle control head. These messages are archived as event data. One preprogrammed message relates to incidents in which operators call for a security response. The occurrence of a security-related incident during the prior month is 
estimated to increase an operator's absence likelihood by nearly .8 percentage points. Silent-alarm messages can also be transmitted, activating a microphone on the vehicle. TriMet has experienced occasional "false positive" silent-alarm events, which represents measurement error and may explain the lack of significance of this variable.

Operators expect their vehicles to be maintained in a good state of repair. When vehicles are not functioning properly, or when they break down in service, this can affect both the operator's job satisfaction and the behavior of customers on board. Operators' absence likelihoods are estimated to increase progressively with the state of inoperability of their vehicles, reaching a maximum with lost-service events. The occurrence of such an event during the prior month is estimated to increase absence likelihoods by nearly .3 percentage points.

The stress associated with navigating a large vehicle in congested city traffic is compounded when operators have to take evasive actions to avoid collisions. When such an incident occurred in the prior month, the estimated absence likelihood increased by nearly .7 percentage points. One would expect accidents to have an even greater effect, although this is not born out in the associated parameter estimate. Most accident incidents result in no injuries and fairly minor damage, such as a broken mirror. More differentiation of accident events with respect to severity is probably needed.

Reported symptoms of fatigue, illness, or substance abuse are the basis of "Fit-for-Duty" events, which occurred very rarely among operators in the sample. However, as one might expect, when such an event occurred in the prior month, it had a substantial effect on the estimated absence likelihood, with an increase of 1.5 percentage points.

\subsection{CUSTOMER RELATIONS}

Riders experience operators' delivery of service firsthand, and some are motivated to report positively or negatively on their experiences. A complaint about unsafe operation of a vehicle in the prior month is estimated to have the greatest positive effect on operators' estimated absence likelihood, followed by complaints related to service delivery (e.g., early and late departs, pass-ups, missed service), and rude or unprofessional treatment by an operator.

TriMet is in the process of deploying automated voice annunciation (AVA) technology on new bus acquisitions. On vehicles without AVA systems, operators are supposed to call out major stops. Stop announcement commendations call attention to those operators who are diligent in performing this task, and such commendations are estimated to have a negative effect on their estimated absence likelihood. Interestingly, commendations for all other reasons are estimated to increase rather than reduce operators' absence likelihood. It may be that more gregarious operators have a greater tendency to stimulate a greater number of both positive and negative responses from customers, while more even-tempered operators who draw less attention from customers tend to be more likely to show up (Jacobs et al., 1996). 


\subsection{OPERATOR FIXED EFFECTS}

Nearly $60 \%$ of the operators in the sample have full-time status and completed more than 50 runs over the two-year period. The parameter estimate for each of these operators

represents their differential absence likelihood compared to the other $40 \%$. Including the fixed effects in the model allows us to recognize the role of person-specific attributes in influencing absence likelihood. The influence of these attributes can be interpreted in several ways. First, they account for absence-related personal influences that are not already represented in the extensive array of variables in the model, such as a person's work ethic, job and life satisfaction, or physical/health constitution. Second, the fixed effects provide a means of recognizing that operators react differently to the various absence-inducing aspects of their jobs. Some may have dispositions that are more resistant to the various stresses of work than others. Thus, there is potential value in comparing parameter estimates of the models with and without fixed effects to distinguish factors whose absence effects are consistently represented across all operators from factors whose absence effects vary by operator.

The frequency distribution of the fixed effects estimated for 778 bus operators is shown in Figure 1. Controlling for the effects of all other variables, about $70 \%$ of the fixed effect operators are estimated to be less likely to be absent than the excluded group. However, there is also an extended right tail in the distribution where the estimated differential absence likelihoods of a fairly small number of operators are quite substantial. Further examination of absences among the fixed effects operators finds that the group comprising fixed effect estimates of -.08 and lower accounts for $8.5 \%$ of the selected operators and $1.5 \%$ of absences, while the group comprising fixed effect estimates of .08 and higher accounts for $7.6 \%$ of the selected operators and $21.4 \%$ of absences.

The introduction of operator fixed effects in the absence model has a noticeable effect on some of the parameter estimates. Among variables representing personal characteristics, the sign of the parameter estimate for African-American operators reverses, indicating that this group's initially lower absence likelihood estimate was the result of more regular attendance among a select subgroup of full-time African-American operators rather than being a reflection of a group-wide phenomenon.

Among the assigned work variables, the positive absence likelihood estimated for the Merlo garage disappears when fixed effects are introduced, indicating the presence of a subgroup of comparatively absence-prone full-time operators rather than a garage-level issue. The estimated absence effects of scheduled overtime also disappear in the fixed effects model, likely reflecting work selection effects of full-time-operator preferences for overtime. The same selection effect interpretation may also hold for the differential absence effects initially estimated across route types. 
Figure 1: Frequency Distribution of Absence Model Operator Fixed

Effects

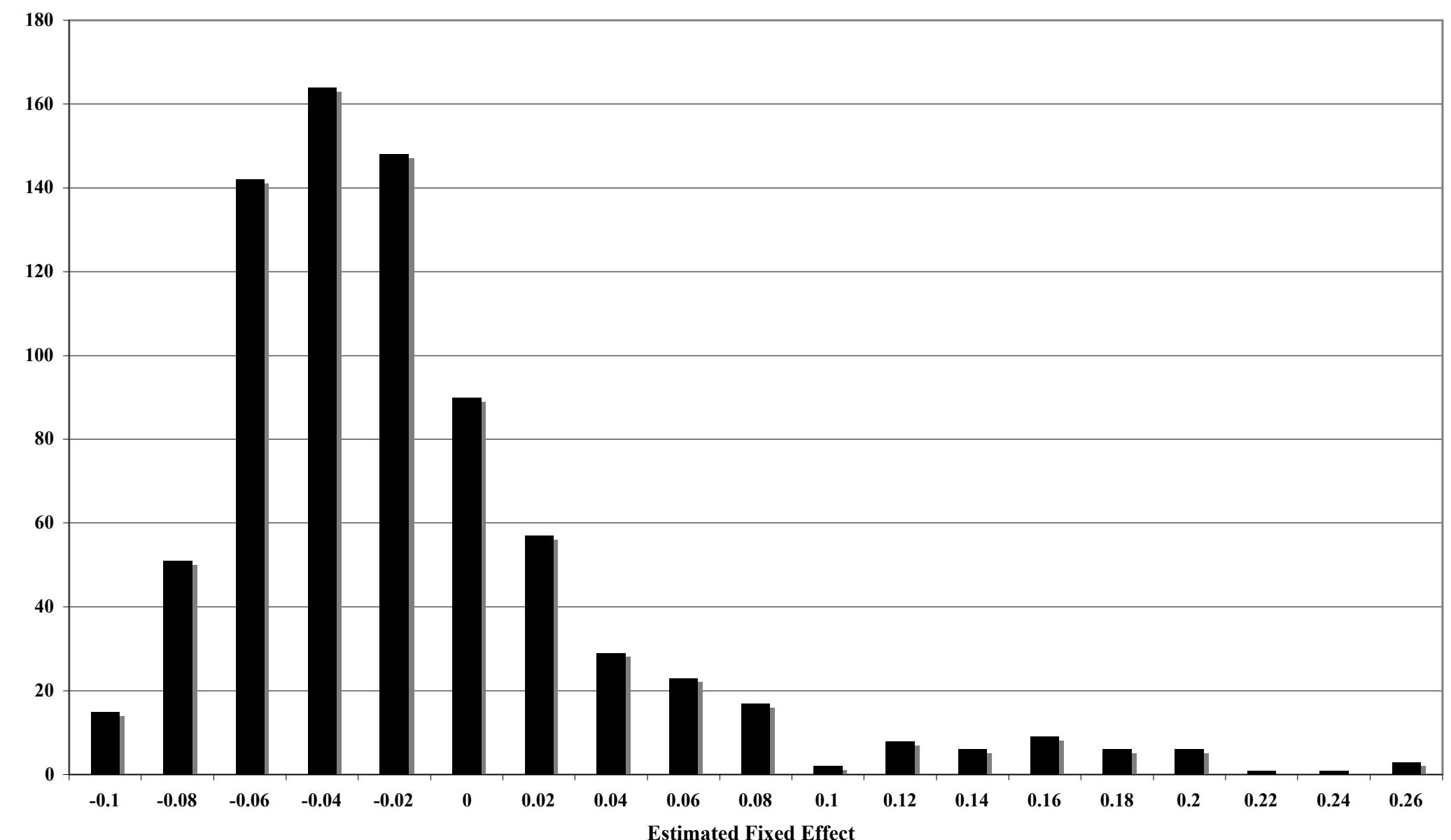


Among the service delivery variables, the absence effect initially estimated for vehiclerelated malfunctions appears to be confined to a subgroup of full-time operators. Finally, among the customer relations variables, the initially estimated absence effects associated with service delivery complaints and both commendation variables also disappear when operator fixed effects are introduced.

\subsection{OVERALL MODEL PERFORMANCE}

Considering that the bus and rail absence models were estimated from operator microdata (i.e., daily absence or attendance), the relatively low proportion of explained variance is to be expected. Adding fixed effects triples the proportion of explained variance in the bus-operator model and doubles the proportion of explained variance in the rail-operator model. The increase in explained variance attributable to the operator fixed effects indicates the importance of heterogeneous personal traits in analyzing absence behavior.

Both linear probability and logit estimation methods were applied to the bus- and railoperator absence models. Whereas linear probability estimates proved quite stable, logit estimates were very unstable when the nearly 800 bus-operator fixed effect variables were included. As Heckman (1978) has noted, the efficiency of linear probability estimation approaches that of logit estimation. The exact least squares estimates of the linear probability model also ensure a global optimum, while the iterative maximum likelihood estimates of the logit model do not. However, absence probabilities estimated by a linear probability model are not bound by zero and one, as they are in a logit model.

In the present case, the number of bus-operator observations with probability estimates less than zero totaled 8,173 (2.1\%) in the model without fixed effects and 26,899 (6.9\%) in the model with fixed effects. Results for the rail models were similar. Closer examination of the records with estimated negative probabilities in the bus fixed effect model showed over-representation of Asian (.08 v. .04 overall) and Hispanic (.06 v. 03) operators, older (53.8 v. 50.8 years) and more experienced (12.4 v. 11.4 years) operators, and regular-relief operators (.43 v. .34), while full-time operators with split assignments were underrepresented (.01 v. .11). Operators with negative estimated probabilities also reported fewer security incidents (.10 v. .18), as well as lost-service (.36 v. .54) and roadcall (.26 v. .35) events. Generally, each of these distinctions moves the estimated marginal absence probability toward zero and, when they occur jointly, can send the estimate below zero. 


\subsection{CONCLUSIONS}

This report has analyzed the effects of personal characteristics, aspects of assigned work and service delivery, temporal factors, and customer relations on short-duration absences of transit operators. The approach takes advantage of detailed information recovered from transit ITS technologies in combination with other information maintained within an enterprise data system, all of which can be related to individual operators.

The findings of the research can be used to support the extraboard planning process. Extraboard planning can now account for the absences consequences of changes in the demographic composition and employment status of regular operators; seasonality differentials; and changes in the composition of assigned work. At the tactical planning level, the results indicate that it would be wise to avoid scheduling training activities (which remove regular-duty operators from their assignments) during winter months or on any Thursday or Friday. The same can be said in granting personal holidays.

The research findings may also contribute to strategic aspects of operations planning in several ways. First, the results indicate that the cost effectiveness of split assignments is diminished by more frequent absences of operators with these work assignments. Breaking full-time splits into part-time straight runs would lead to lower absence rates. Second, the reliance on scheduled overtime as a general objective in operations planning should be carefully considered. Examination of the signup process indicates that operators generally prefer overtime, but from an absence standpoint, scheduled overtime ought to be limited to straight runs.

Changing several provisions in the current labor agreement would have potentially beneficial effects in reducing operator absences. First, should a full-time operator wish to transition to part-time status, her accumulated seniority rights would be lost. This acts as a substantial disincentive to senior operators who might otherwise be interested in being retained in part-time service following retirement. Operators with generally the best attendance records are thus effectively preempted from continued service.

The seniority losses in transitioning from full- to part-time status may be even more consequential for women operators. Although all full-time operators must first serve on a part-time basis, some chose to remain as part-time operators. About one-third of parttime operators in the study have been employed for more than two years, indicating that they prefer this status. Women comprise $46 \%$ of the "permanent" part-time operators, as compared to $28 \%$ of full-time operators. The absence model also estimated absence likelihoods among part-time women to be lower than the likelihoods among part-time men, where the reverse was the case among full-time operators. Given the current seniority barrier, the effective choice facing full-time women operators dealing with pressing non-work demands is to either quit or absent themselves more frequently. 
Second, economic incentives have been used in the transit industry to promote regular attendance and safe operation (Hartman et al., 1994). In the current labor agreement, the economic incentive to attend is found in the opportunity to cash out accumulated unused sick leave at retirement. The cash-out provision for the maximum sick-leave balance at retirement would generate more than $\$ 400$ per month in additional pension income. Attractive as this incentive may be, its effective present value to an operator considering whether or not to report for work today is likely to be highly discounted, especially if that operator is among the younger cohort that was found to be most absent-prone. A potentially more effective alternative would be to structure an attendance incentive to provide an annual payout, following the example of the transit properties studied by Hartman et al. (1994).

Although the findings from this analysis relate to the experiences of one transit agency, the approach draws on data and information that are becoming more widely available in the industry. Replication is thus a fairly straightforward task. More generally, the depth of analysis of this issue made possible following the deployment of new technology and the increasing ability to integrate data from various information systems was hardly imaginable in the transit industry just 10 years ago. 


\subsection{REFERENCES}

Allen, S. 1981a. An empirical model of work attendance. The Review of Economics and Statistics, 63, 77-87.

Allen, S. 1981b. Compensation, safety, and absenteeism: Evidence from the paper industry. Industrial and Labor Relations Review, 34, 207-218.

Allen, S. 1984. Trade unions, absenteeism, and exit-voice. Industrial and Labor Relations Review, 37, 331-345.

Barmby, T., Orme, C., and Treble, J. 1995. Worker absence histories: a panel data study. Labour Economics, 2, 53-65.

Beehr, T. and Gupta, N. 1978. A note on the structure of employee withdrawal. Organizational Behavior and Human Performance, 21, 73-79.

Chadwick-Jones, J., Nicholson, N. and Brown, C. 1982. Social Psychology of Absenteeism. New York, NY: Praeger.

Chelius, J. 1981. Understanding absenteeism: The potential contribution of economic theory. Journal of Business Research, 9, 409-418.

Cunradi, C., Greiner, B., Ragland, D. and Fisher, J. 2005. Alcohol, stress-related factors, and short-term absenteeism among urban transit operators. Journal of Urban Health, 82, 43-57.

DeAnnuntis, C. and Morris, W. 2007. Transit Extraboard Management: Optimum Sizing and Strategies. Tampa, FL: Center for Urban Transportation Research, University of South Florida.

Delgado, M. and Kniesner, T. 1997. Count data models with variance of unknown form: An application to a hedonic model of worker absenteeism. The Review of Economics and Statistics, 79, 41-49.

Dionne, G. and Dostie, B. 2007. New evidence on the determinants of absenteeism using linked employer-employee data. Industrial and Labor Relations Review, 61, 108-120.

Drago, R. and Wooden, M. 1992. The determinants of labor absence: Economic factors and workgroup norms across countries. Industrial and Labor Relations Review, 45, 764-778. 
Dunn, L. and Youngblood, S. 1986. Absenteeism as a mechanism for approaching an optimal labor market equilibrium: An empirical study. The Review of Economics and Statistics, 68, 668-674.

Evans, G., Johansson, G. and Rydstedt, L. 1999. Hassles on the job: A study of a job intervention with urban bus drivers. Journal of Organizational Behavior, 20, 199-208.

Farrell, D. and Stamm, C. 1988. Meta-analysis of the correlates of employee absence. Human Relations, 41, 211-227.

Fichman, M. 1984. A theoretical approach to understanding employee absence. In P. Goodman and R. Atkin (Eds.), Absence: New Approach to Understanding, Measuring and Managing Employee Absence. San Francisco, CA: Jossey-Bass, 158-193.

Fitzgibbons, D. and Moch, M. 1980. Employee absenteeism: A multivariate analysis with replication. Organizational Behavior and Human Performance, 26, 349372.

Furth, P., Hemily, B., Muller, T. and Strathman, J. 2006. TCRP Report 113: Using Archived AVL-APC Data to Improve Transit Performance and Management. Washington, DC: Transit Cooperative Research Program, Transportation Research Board, National Research Council.

Gardell, B., Aaronson, G. and Barkloff, K. 1982. The Working Environment for Local Public Transport Personnel. Stockholm: Swedish Work Environment Fund.

Gramm, W. 1975. Household utility maximization and the working wife. American Economic Review, 65, 90-100.

Greiner, B., Krause, N., Ragland, D. and Fisher, J. 1998. Objective stress factors, accidents, and absenteeism in transit operators: A theoretical framework and empirical evidence. Journal of Occupational Health Psychology, 3, 130-146.

Gronau, R. 1977. Leisure, home production and work: The theory of the allocation of time revisited. Journal of Political Economy, 85, 1099-1123.

Hackett, R. and Guion, R. 1985. A reevaluation of the absenteeism-job satisfaction relationship. Organizational Behavior and Human Decision Processes, 35, 340381.

Hartman, R., Kurtz, E. and Moser, E. 1994. Synthesis of Transit Practice 3: Incentive Programs to Improve Transit Employee Performance. Washington, DC: Transit Cooperative Research Program, Transportation Research Board, National Research Council. 
Heckman, J. 1978. Dummy endogenous variables in a simultaneous equation system. Econometrica, 46, 931-959.

Hill, J. and Trist, E. 1953. A consideration of industrial accidents and a means of withdrawal from the work situation: A study of their relation to other absences in an iron and steel works. Human Relations, 6, 357-380.

Jacobs, R., Conte, J., Day, D., Silva, J. and Harris, R. 1996. Selecting bus drivers: Multiple predictors on validity, and multiple estimates of utility. Human Performance, 9, 199-217.

Keller, R. 1983. Predicting absenteeism from prior absenteeism, attitudinal factors, and nonattitudinal factors. Journal of Applied Psychology, 68, 536-540.

Kenyon, P. and Dawkins, P. 1989. A time series analysis of labour absence in Australia. The Review of Economics and Statistics, 71, 232-239.

Kohler, S. and Mathieu, J. 1993. Individual characteristics, work perceptions, and affective reactions influences on differentiated absence criteria. Journal of Organizational Behavior, 14, 515-530.

Kompier, M., Mulders, H., Meijman, T., Boersma, M., Groen, G. and Bullinga, R. 1990. Absence behavior, turnover and disability: A study among city bus drivers in the Netherlands. Work and Stress, 4, 83-89.

Leigh, J. 1981. The effects of union membership on absence from work due to illness. Journal of Labor Research, 2, 329-336.

Leigh, J. 1986. The effects of unemployment and the business cycles on absenteeism. Journal of Economics and Business, 37, 159-170.

Long, L. and Perry, J. 1985. Economic and occupational causes of transit operator absenteeism: a review of research. Transport Reviews, 5, 247-267.

Muchinski, P. 1977. Employee absenteeism: A review of the literature. Journal of Vocational Behavior, 10, 316-340.

Nicholson, N., Brown, C. and Chadwick-Jones, J. 1976. Absence from work and job satisfaction. Journal of Applied Psychology, 61, 729-737.

Porter, L. and Steers, R. 1973. Organizational, work, and personal factors in employee turnover and absenteeism. Psychological Bulletin, 80, 151-176.

Shiftan, Y. and Wilson, N. 2001. The absence consequences of overtime in the transit industry. Journal of Public Transportation, 3, 25-40. 
Shopes, R. 2008. HART drivers' use of FMLA questioned. The Tampa Tribune. February 8.

Stagner, R. and Rosen, H. 1965. The psychology of union-management relations. Belmont, CA: Wadsworth.

Steers, R. and Rhodes, S. 1978. Major influences on employee attendance: A process model. Journal of Applied Psychology, 63, 391-407.

Steers, R. and Rhodes, S. 1984. Knowledge and speculation about absenteeism. In P. Goodman and R. Atkin, (Eds.), Absence: New Approach to Understanding, Measuring and Managing Employee Absence. San Francisco, CA: Jossey-Bass, 229-275.

Strathman, J., Dueker, K., Kimpel, T., Gerhart, R. and Callas, S. 2002. Evaluation of transit operations: Data applications of TriMet's automated bus dispatching system. Transportation, 29, 321-345.

Strathman, J., Kimpel, T., Broach, J., Wachana, P., Coffel, K., Callas, S., Elliot, B. and Elmore-Yalch, R. 2008. TCRP Report 126: Leveraging ITS Data for Transit Market Research: A Practitioner's Guidebook. Washington, DC: Transit Cooperative Research Program, Transportation Research Board, National Research Council.

Tse, J., Flin, R. and Mearns, K. 2006. Bus driver well-being review: 50 years of research. Transportation Research Part F, 9, 89-114.

US Department of Labor. 2007. Family and Medical Leave Act Regulations: A Report on the Department of Labor's Request for Information, 2007 Update. Washington, DC: Wage and Hour Division, Employment Standards Administration.

Volinski, J. 1999. Synthesis of Transit Practice 33: Practices in Assuring Employee Availability. Washington, DC: Transit Cooperative Research Program, Transportation Research Board, National Research Council.

Volpe National Transportation Systems Center. 2005. Advanced Public Transportation Systems Deployment in the United States: Year 2004 Update. Washington, DC: Federal Transit Administration, U.S. Department of Transportation.

Watson, C. 1981. An evaluation of some aspects of the Steers and Rhodes model of employee attendance. Journal of Applied Psychology, 66, 385-389.

Winkleby, M., Ragland, D., Fisher, J. and Syme, S. 1988. Excess risk of sickness and disease in bus drivers: A review and synthesis of epidemiological studies. International Journal of Epidemiology, 17, 255-262. 


\section{APPENDIX}

Variable Descriptions and Descriptive Statistics for Bus and Rail Operator Samples

(Standard deviations in parentheses)

\begin{tabular}{|c|c|c|c|}
\hline Variable & Description & $\begin{array}{l}\text { Bus Operator } \\
\text { Sample }\end{array}$ & $\begin{array}{l}\text { Rail Operator } \\
\text { Sample }\end{array}$ \\
\hline Absent & $\begin{array}{l}\text { A dummy variable equaling one when the operator was absent on the assigned } \\
\text { workday and zero otherwise }\end{array}$ & $\begin{array}{l}.048 \\
(.21)\end{array}$ & $\begin{array}{l}.048 \\
(.21)\end{array}$ \\
\hline \multicolumn{4}{|l|}{ Personal Characteristics } \\
\hline Age & Operator's age on the assigned workday & $\begin{array}{l}50.84 \\
(8.95)\end{array}$ & $\begin{array}{l}50.08 \\
(7.94)\end{array}$ \\
\hline Male & A dummy variable equaling one if the operator is male and zero otherwise & $\begin{array}{l}.68 \\
(.46) \\
\end{array}$ & $\begin{array}{l}.74 \\
(.44) \\
\end{array}$ \\
\hline Female & A dummy variable equaling one if the operator is female and zero otherwise & $\begin{array}{l}.32 \\
(.46)\end{array}$ & $\begin{array}{l}.26 \\
(.44)\end{array}$ \\
\hline Caucasian & A dummy variable equaling one if the operator's race is Caucasian and zero otherwise & $\begin{array}{l}.79 \\
(.41)\end{array}$ & $\begin{array}{c}.87 \\
(.34)\end{array}$ \\
\hline African-American & $\begin{array}{l}\text { A dummy variable equaling one if the operator's race is African-American and zero } \\
\text { otherwise }\end{array}$ & $\begin{array}{l}.14 \\
(.34)\end{array}$ & $\begin{array}{l}.06 \\
(.23)\end{array}$ \\
\hline Asian & $\begin{array}{l}\text { A dummy variable equaling one if the operator's race is Asian or Pacific Islander and } \\
\text { zero otherwise }\end{array}$ & $\begin{array}{c}.04 \\
(.18)\end{array}$ & $\begin{array}{c}.03 \\
(.18)\end{array}$ \\
\hline Hispanic & $\begin{array}{l}\text { A dummy variable equaling one if the operator's ethnicity is Hispanic and zero } \\
\text { otherwise }\end{array}$ & $\begin{array}{c}.03 \\
(.18)\end{array}$ & $\begin{array}{l}.03 \\
(.16)\end{array}$ \\
\hline Years Experience & Operator's TriMet experience (in years) on the assigned workday & $\begin{array}{l}11.39 \\
(8.48)\end{array}$ & $\begin{array}{l}11.46 \\
(5.13)\end{array}$ \\
\hline Regular Full Time & $\begin{array}{l}\text { A dummy variable equaling one when the operator's employment status was "Regular } \\
\text { Full Time" on the assigned workday and zero otherwise }\end{array}$ & $\begin{array}{l}.70 \\
(.46)\end{array}$ & $\begin{array}{c}1.0 \\
(.00)\end{array}$ \\
\hline Part Time & $\begin{array}{l}\text { A dummy variable equaling one when the operator's employment status was "Part } \\
\text { Time" on the assigned workday and zero otherwise }\end{array}$ & $\begin{array}{l}.30 \\
(.46)\end{array}$ & -- \\
\hline Probationary & $\begin{array}{l}\text { A dummy variable equaling one when the operator's employment status was } \\
\text { "Probationary" on the assigned workday (i.e., limited to operators during their initial } \\
\text { six-month term of part-time employment) and zero otherwise }\end{array}$ & $\begin{array}{l}.04 \\
(.19)\end{array}$ & -- \\
\hline
\end{tabular}




\begin{tabular}{|c|c|c|c|}
\hline $\begin{array}{l}\text { Assigned Work } \\
\text { Characteristics }\end{array}$ & & & \\
\hline Center Garage & $\begin{array}{l}\text { A dummy variable equaling one when the bus operator's pullout on the assigned } \\
\text { workday was from the Center St. garage and zero otherwise }\end{array}$ & $\begin{array}{l}.44 \\
(.50) \\
\end{array}$ & -- \\
\hline Powell Garage & $\begin{array}{l}\text { A dummy variable equaling one when the bus operator's pullout on the assigned } \\
\text { workday was from the Powell Ave. garage and zero otherwise }\end{array}$ & $\begin{array}{l}.34 \\
(.47)\end{array}$ & -- \\
\hline Merlo Garage & $\begin{array}{l}\text { A dummy variable equaling one when the bus operator's pullout on the assigned } \\
\text { workday was from the Merlo Dr. garage and zero otherwise }\end{array}$ & $\begin{array}{l}.22 \\
(.41)\end{array}$ & -- \\
\hline Ruby Junction Yard & $\begin{array}{l}\text { A dummy variable equaling one when the rail operator's pullout on the assigned } \\
\text { workday was from the Ruby Junction Yard and zero otherwise }\end{array}$ & -- & $\begin{array}{l}.41 \\
(.49)\end{array}$ \\
\hline Elmonica Yard & $\begin{array}{l}\text { A dummy variable equaling one when the rail operator's pullout on the assigned } \\
\text { workday is from the Elmonica Yard and zero otherwise }\end{array}$ & -- & $\begin{array}{l}.59 \\
(.49)\end{array}$ \\
\hline Straight Run & $\begin{array}{l}\text { A dummy variable equaling one when the operator's assigned work was comprised of } \\
\text { an uninterrupted block of time and zero otherwise }\end{array}$ & $\begin{array}{l}.67 \\
(.47)\end{array}$ & $\begin{array}{l}.88 \\
(.33)\end{array}$ \\
\hline Regular Relief & $\begin{array}{l}\text { A dummy variable equaling one when the operator's assigned work was in relief of } \\
\text { other operators on their regular day off and zero otherwise }\end{array}$ & $\begin{array}{l}.34 \\
(.47)\end{array}$ & $\begin{array}{l}.46 \\
(.50)\end{array}$ \\
\hline Vacation Relief & $\begin{array}{l}\text { A dummy variable equaling one when the operator's assigned work was in relief of } \\
\text { another operator who was on vacation and zero otherwise }\end{array}$ & $\begin{array}{c}.04 \\
(.19) \\
\end{array}$ & $\begin{array}{c}.03 \\
(.18) \\
\end{array}$ \\
\hline Full-Time Split & $\begin{array}{l}\text { A dummy variable equaling one when a Full-Time operator's assigned work was split } \\
\text { between two distinct blocks of time during the workday and zero otherwise }\end{array}$ & $\begin{array}{c}0.11 \\
(.31) \\
\end{array}$ & $\begin{array}{c}1.12 \\
(.33) \\
\end{array}$ \\
\hline Part-Time Split & $\begin{array}{l}\text { A dummy variable equaling one when a Part-Time operator's assigned work was split } \\
\text { between two distinct blocks of time during the workday and zero otherwise }\end{array}$ & $\begin{array}{l}.22 \\
(.42)\end{array}$ & -- \\
\hline PM Run & $\begin{array}{l}\text { A dummy variable equaling one when an operator's scheduled pull-in on the assigned } \\
\text { workday occurred between 4:30 and } 11 \text { p.m., and zero otherwise }\end{array}$ & $\begin{array}{l}.50 \\
(.50)\end{array}$ & $\begin{array}{l}1.19 \\
(.39)\end{array}$ \\
\hline Day Run & $\begin{array}{l}\text { A dummy variable equaling one when an operator's scheduled pull-in on the assigned } \\
\text { workday occurred before 4:30 p.m. and zero otherwise }\end{array}$ & $\begin{array}{l}.31 \\
(.46)\end{array}$ & $\begin{array}{l}.41 \\
(.49)\end{array}$ \\
\hline Night Run & $\begin{array}{l}\text { A dummy variable equaling one when an operator's scheduled pull-in on the assigned } \\
\text { workday occurred after } 11 \text { p.m. and zero otherwise }\end{array}$ & $\begin{array}{c}.19 \\
(.39)\end{array}$ & $\begin{array}{c}.40 \\
(.49)\end{array}$ \\
\hline Scheduled Overtime & $\begin{array}{l}\text { Operator's total scheduled overtime hours during the month prior to the assigned } \\
\text { workday }\end{array}$ & $\begin{array}{c}19.05 \\
(17.03)\end{array}$ & $\begin{array}{c}21.09 \\
(16.33)\end{array}$ \\
\hline $\begin{array}{l}\text { Trunk Radial, Frequent } \\
\text { Service }\end{array}$ & $\begin{array}{l}\text { A dummy variable equaling one when a bus operator's workday assignment involved a } \\
\text { route classified as a frequent service Trunk Radial (i.e., headways } 15 \text { minutes and } \\
\text { under) and zero otherwise }\end{array}$ & $\begin{array}{c}.56 \\
(.50)\end{array}$ & -- \\
\hline
\end{tabular}




\begin{tabular}{|c|c|c|c|}
\hline $\begin{array}{l}\text { Trunk Radial, Secondary } \\
\text { Service }\end{array}$ & $\begin{array}{l}\text { A dummy variable equaling one when a bus operator's workday assignment involved a } \\
\text { route classified as a secondary service Trunk Radial (i.e., headways greater than } 15 \\
\text { minutes) and zero otherwise }\end{array}$ & $\begin{array}{l}.49 \\
(.50)\end{array}$ & -- \\
\hline Crosstown & $\begin{array}{l}\text { A dummy variable equaling one when a bus operator's workday assignment involved a } \\
\text { route classified as a Crosstown and zero otherwise }\end{array}$ & $\begin{array}{c}.54 \\
(.50) \\
\end{array}$ & -- \\
\hline Feeder & $\begin{array}{l}\text { A dummy variable equaling one when a bus operator's workday assignment involved a } \\
\text { route classified as a Feeder and zero otherwise }\end{array}$ & $\begin{array}{l}.31 \\
(.46)\end{array}$ & -- \\
\hline Peak Express & $\begin{array}{l}\text { A dummy variable equaling one when a bus operator's workday assignment involved a } \\
\text { route classified as a Peak Express and zero otherwise }\end{array}$ & $\begin{array}{l}.15 \\
(.35)\end{array}$ & -- \\
\hline \multicolumn{4}{|l|}{ Temporal Characteristics } \\
\hline 2006 & $\begin{array}{l}\text { A dummy variable equaling one when an operator's assigned workday occurred in } \\
2006 \text { and zero otherwise }\end{array}$ & $\begin{array}{c}.52 \\
(.50)\end{array}$ & $\begin{array}{l}.52 \\
(.50) \\
\end{array}$ \\
\hline 2007 & $\begin{array}{l}\text { A dummy variable equaling one when an operator's assigned workday occurred in } \\
2007 \text { and zero otherwise }\end{array}$ & $\begin{array}{l}.48 \\
(.50)\end{array}$ & $\begin{array}{l}.48 \\
(.50)\end{array}$ \\
\hline January & $\begin{array}{l}\text { A dummy variable equaling one when an operator's assigned workday occurred in the } \\
\text { month of January and zero otherwise }\end{array}$ & $\begin{array}{c}.08 \\
(.28) \\
\end{array}$ & $\begin{array}{l}08 \\
(.28) \\
\end{array}$ \\
\hline February & $\begin{array}{l}\text { A dummy variable equaling one when an operator's assigned workday occurred in the } \\
\text { month of February and zero otherwise }\end{array}$ & $\begin{array}{c}.08 \\
(.27)\end{array}$ & $\begin{array}{l}.08 \\
(.27)\end{array}$ \\
\hline March & $\begin{array}{l}\text { A dummy variable equaling one when an operator's assigned workday occurred in the } \\
\text { month of March and zero otherwise }\end{array}$ & $\begin{array}{l}.09 \\
(.29)\end{array}$ & $\begin{array}{l}.09 \\
(.29) \\
\end{array}$ \\
\hline April & $\begin{array}{l}\text { A dummy variable equaling one when an operator's assigned workday occurred in the } \\
\text { month of April and zero otherwise }\end{array}$ & $\begin{array}{l}.09 \\
(.28)\end{array}$ & $\begin{array}{l}.09 \\
(.28)\end{array}$ \\
\hline May & $\begin{array}{l}\text { A dummy variable equaling one when an operator's assigned workday occurred in the } \\
\text { month of May and zero otherwise }\end{array}$ & $\begin{array}{l}.09 \\
(.28)\end{array}$ & $\begin{array}{l}.08 \\
(.28)\end{array}$ \\
\hline June & $\begin{array}{l}\text { A dummy variable equaling one when an operator's assigned workday occurred in the } \\
\text { month of June and zero otherwise }\end{array}$ & $\begin{array}{l}.09 \\
(.29)\end{array}$ & $\begin{array}{l}.09 \\
(.28)\end{array}$ \\
\hline July & $\begin{array}{l}\text { A dummy variable equaling one when an operator's assigned workday occurred in the } \\
\text { month of July and zero otherwise }\end{array}$ & $\begin{array}{c}.09 \\
(.28) \\
\end{array}$ & $\begin{array}{l}.08 \\
(.28) \\
\end{array}$ \\
\hline August & $\begin{array}{l}\text { A dummy variable equaling one when an operator's assigned workday occurred in the } \\
\text { month of August and zero otherwise }\end{array}$ & $\begin{array}{c}.09 \\
(.29)\end{array}$ & $\begin{array}{l}.09 \\
(.28)\end{array}$ \\
\hline September & $\begin{array}{l}\text { A dummy variable equaling one when an operator's assigned workday occurred in the } \\
\text { month of September and zero otherwise }\end{array}$ & $\begin{array}{c}.08 \\
(.28)\end{array}$ & $\begin{array}{l}.09 \\
(.28)\end{array}$ \\
\hline
\end{tabular}




\begin{tabular}{|c|c|c|c|}
\hline October & $\begin{array}{l}\text { A dummy variable equaling one when an operator's assigned workday occurred in the } \\
\text { month of October and zero otherwise }\end{array}$ & $\begin{array}{l}.09 \\
(.29) \\
\end{array}$ & $\begin{array}{l}.09 \\
(.29) \\
\end{array}$ \\
\hline November & $\begin{array}{l}\text { A dummy variable equaling one when an operator's assigned workday occurred in the } \\
\text { month of November and zero otherwise }\end{array}$ & $\begin{array}{c}.09 \\
(.28)\end{array}$ & $\begin{array}{l}.09 \\
(.28)\end{array}$ \\
\hline December & $\begin{array}{l}\text { A dummy variable equaling one when an operator's assigned workday occurred in the } \\
\text { month of December and zero otherwise }\end{array}$ & $\begin{array}{c}.04 \\
(.20) \\
\end{array}$ & $\begin{array}{l}.05 \\
(.21) \\
\end{array}$ \\
\hline Monday & $\begin{array}{l}\text { A dummy variable equaling one when an operator's assigned workday occurred on a } \\
\text { Monday and zero otherwise }\end{array}$ & $\begin{array}{c}.17 \\
(.37) \\
\end{array}$ & $\begin{array}{l}.15 \\
(.36) \\
\end{array}$ \\
\hline Tuesday & $\begin{array}{l}\text { A dummy variable equaling one when an operator's assigned workday occurred on a } \\
\text { Tuesday and zero otherwise }\end{array}$ & $\begin{array}{c}.16 \\
(.36)\end{array}$ & $\begin{array}{l}.14 \\
(.35)\end{array}$ \\
\hline Wednesday & $\begin{array}{l}\text { A dummy variable equaling one when an operator's assigned workday occurred on a } \\
\text { Wednesday and zero otherwise }\end{array}$ & $\begin{array}{c}.17 \\
(.38)\end{array}$ & $\begin{array}{l}.15 \\
(.36) \\
\end{array}$ \\
\hline Thursday & $\begin{array}{l}\text { A dummy variable equaling one when an operator's assigned workday occurred on a } \\
\text { Thursday and zero otherwise }\end{array}$ & $\begin{array}{c}.17 \\
(.38)\end{array}$ & $\begin{array}{l}.15 \\
(.36) \\
\end{array}$ \\
\hline Friday & $\begin{array}{l}\text { A dummy variable equaling one when an operator's assigned workday occurred on a } \\
\text { Friday and zero otherwise }\end{array}$ & $\begin{array}{c}.17 \\
(.37) \\
\end{array}$ & $\begin{array}{l}.15 \\
(.36) \\
\end{array}$ \\
\hline Saturday & $\begin{array}{l}\text { A dummy variable equaling one when an operator's assigned workday occurred on a } \\
\text { Saturday and zero otherwise }\end{array}$ & $\begin{array}{c}.09 \\
(.29) \\
\end{array}$ & $\begin{array}{l}13 \\
(.34) \\
\end{array}$ \\
\hline Sunday & $\begin{array}{l}\text { A dummy variable equaling one when an operator's assigned workday occurred on a } \\
\text { Sunday and zero otherwise }\end{array}$ & $\begin{array}{l}.08 \\
(.26) \\
\end{array}$ & $\begin{array}{l}12 \\
(.32) \\
\end{array}$ \\
\hline Holiday & $\begin{array}{l}\text { A dummy variable equaling one when an operator's assigned workday occurred on a } \\
\text { Holiday (qualifying for time-and-a-half pay) and zero otherwise }\end{array}$ & $\begin{array}{c}.01 \\
(.11) \\
\end{array}$ & $\begin{array}{l}.02 \\
(.13) \\
\end{array}$ \\
\hline $\begin{array}{l}\text { Day Before Regular } \\
\text { Day Off }\end{array}$ & $\begin{array}{l}\text { A dummy variable equaling one when an operator's assigned workday occurred on the } \\
\text { day before a regular day off and zero otherwise }\end{array}$ & $\begin{array}{c}.21 \\
(.40) \\
\end{array}$ & $\begin{array}{l}.20 \\
(.40) \\
\end{array}$ \\
\hline $\begin{array}{l}\text { Day After Regular } \\
\text { Day Off }\end{array}$ & $\begin{array}{l}\text { A dummy variable equaling one when an operator's assigned workday occurred on the } \\
\text { day after a regular day off and zero otherwise }\end{array}$ & $\begin{array}{l}.20 \\
(.40)\end{array}$ & $\begin{array}{l}.20 \\
(.40) \\
\end{array}$ \\
\hline \multicolumn{4}{|l|}{$\begin{array}{l}\text { Service Delivery } \\
\text { Characteristics }\end{array}$} \\
\hline $\begin{array}{l}\text { Prior Month On-Time } \\
\text { Departures v. Peers }\end{array}$ & $\begin{array}{l}\text { Proportion of an operator's departures from time points that are on time (i.e., one } \\
\text { minute early to five minutes late in relation to scheduled departure) minus the } \\
\text { proportion of on-time departures of peer operators (i.e., other operators serving the } \\
\text { same time point during the same time period) during the 30-day period prior to the } \\
\text { assigned workday }\end{array}$ & $\begin{array}{l}.01 \\
(.10)\end{array}$ & $\begin{array}{l}.01 \\
(.08)\end{array}$ \\
\hline Prior Month Early & Proportion of an operator's departures from time points that are early (i.e., more than & -.005 & .003 \\
\hline
\end{tabular}




\begin{tabular}{|c|c|c|c|}
\hline Departures v. Peers & $\begin{array}{l}\text { one minute early in relation to scheduled departure) minus the proportion of early } \\
\text { departures of peer operators (i.e., other operators serving the same time point during } \\
\text { the same time period) during the 30-day period prior to the assigned workday }\end{array}$ & $(.06)$ & $(.05)$ \\
\hline $\begin{array}{l}\text { Prior Month Late } \\
\text { Departures v. Peers }\end{array}$ & $\begin{array}{l}\text { Proportion of an operator's departures from time points that are late (i.e., more than } \\
\text { five minutes late in relation to scheduled departure) minus the proportion of late } \\
\text { departures of peer operators (i.e., other operators serving the same time point during } \\
\text { the same time period) during the 30-day period prior to the assigned workday }\end{array}$ & $\begin{array}{l}-.11 \\
(.08)\end{array}$ & $\begin{array}{l}-.08 \\
(.07)\end{array}$ \\
\hline $\begin{array}{l}\text { Prior Month Average } \\
\text { Speed v. Peers }\end{array}$ & $\begin{array}{l}\text { Operator's mean maximum speed between time points minus the mean maximum } \\
\text { speed of peer operators (operators traveling between the same time points during the } \\
\text { same time period) during the 30-day period prior to the assigned workday }\end{array}$ & $\begin{array}{c}.02 \\
(1.52)\end{array}$ & -- \\
\hline $\begin{array}{l}\text { Prior Month Actual } \\
\text { Layover Time }\end{array}$ & $\begin{array}{l}\text { Operator's actual average layover time divided by actual average revenue time during } \\
\text { the 30-day period prior to the assigned workday }\end{array}$ & $\begin{array}{l}.17 \\
(.52)\end{array}$ & $\begin{array}{l}.16 \\
(.05) \\
\end{array}$ \\
\hline $\begin{array}{l}\text { Prior Month Boardings } \\
\text { Per Revenue Hour }\end{array}$ & $\begin{array}{l}\text { Passenger boardings per revenue hour on service delivered by the operator during the } \\
\text { 30-day period prior to the assigned workday }\end{array}$ & $\begin{array}{l}30.70 \\
(8.65)\end{array}$ & -- \\
\hline $\begin{array}{l}\text { Prior Month Lifts Per } \\
\text { Revenue Hour }\end{array}$ & $\begin{array}{l}\text { Lift operations per revenue hour on service delivered by the operator during the } 30- \\
\text { day period prior to the assigned workday }\end{array}$ & $\begin{array}{l}.18 \\
(.11) \\
\end{array}$ & -- \\
\hline $\begin{array}{l}\text { Prior Month Security } \\
\text { Response Requests }\end{array}$ & $\begin{array}{l}\text { Number of text-coded requests for security response transmitted by the operator to } \\
\text { the dispatch center via the bus control head during the 30-day period prior to the } \\
\text { assigned workday }\end{array}$ & $\begin{array}{l}.18 \\
(.49)\end{array}$ & -- \\
\hline $\begin{array}{l}\text { Prior Month Road-Trade } \\
\text { Requests }\end{array}$ & $\begin{array}{l}\text { Number of text-coded requests for a replacement bus (for a bus in service) } \\
\text { transmitted by the operator to the dispatch center via the bus control head during the } \\
\text { 30-day period prior to the assigned workday }\end{array}$ & $\begin{array}{l}.35 \\
(.69)\end{array}$ & -- \\
\hline $\begin{array}{l}\text { Prior Month Lost-Service } \\
\text { Incidents }\end{array}$ & $\begin{array}{l}\text { Number of text-coded lost service (i.e., bus out of service, operable or non-operable) } \\
\text { messages transmitted by the operator to the dispatch center via the control head on } \\
\text { the bus during the 30-day period prior to the assigned workday }\end{array}$ & $\begin{array}{l}.54 \\
(.87)\end{array}$ & -- \\
\hline $\begin{array}{l}\text { Prior Month Road-Call } \\
\text { Requests }\end{array}$ & $\begin{array}{l}\text { Number of text-coded road-call (i.e., bus out of service, non-operable) requests } \\
\text { transmitted by the operator to the dispatch center via the bus control head during the } \\
\text { 30-day period prior to the assigned workday }\end{array}$ & $\begin{array}{l}.35 \\
(.63)\end{array}$ & -- \\
\hline $\begin{array}{l}\text { Prior Month Traffic-Delay } \\
\text { Incidents }\end{array}$ & $\begin{array}{l}\text { Number of text-coded delay-related event (e.g., traffic incidents, rail crossings, bridge } \\
\text { lifts) messages transmitted by the operator to the dispatch center via the bus control } \\
\text { head during the 30-day period prior to the assigned workday }\end{array}$ & $\begin{array}{l}.12 \\
(.37)\end{array}$ & -- \\
\hline $\begin{array}{l}\text { Prior Month Accidents or } \\
\text { Incidents Witnessed }\end{array}$ & $\begin{array}{l}\text { Number of events witnessed and transmitted by the operator to the dispatch center as } \\
\text { text-coded messages via the bus control head during the 30-day period prior to the } \\
\text { assigned workday }\end{array}$ & $\begin{array}{l}.03 \\
(.17)\end{array}$ & -- \\
\hline
\end{tabular}




\begin{tabular}{|c|c|c|c|}
\hline $\begin{array}{l}\text { Prior Month Passenger } \\
\text { Slip, Trip or Fall Incidents }\end{array}$ & $\begin{array}{l}\text { Number of passenger "slip, trip, or fall" incidents that occurred in the operator's } \\
\text { service during the 30-day period prior to the assigned workday }\end{array}$ & $\begin{array}{l}.03 \\
(.18) \\
\end{array}$ & $\begin{array}{c}.06 \\
(.23) \\
\end{array}$ \\
\hline Prior Month Accidents & $\begin{array}{l}\text { Number of accidents involving the operator's vehicle that occurred during the 30-day } \\
\text { period prior to the assigned workday }\end{array}$ & $\begin{array}{l}.07 \\
(.28) \\
\end{array}$ & $\begin{array}{c}.04 \\
(.20) \\
\end{array}$ \\
\hline $\begin{array}{l}\text { Prior Month Evasive } \\
\text { Action Incidents }\end{array}$ & $\begin{array}{l}\text { Number of incidents requiring the operator to take evasive action during the 30-day } \\
\text { period prior to the assigned workday }\end{array}$ & $\begin{array}{l}.01 \\
(.10)\end{array}$ & $\begin{array}{l}.16 \\
(.46)\end{array}$ \\
\hline $\begin{array}{l}\text { Prior Month Vandalism } \\
\text { Incidents }\end{array}$ & $\begin{array}{l}\text { Number of text-coded vandalism of transit property messages transmitted by the } \\
\text { operator to the dispatch center via the bus control head during the 30-day period prior } \\
\text { to the assigned workday }\end{array}$ & $\begin{array}{l}.001 \\
(.04)\end{array}$ & -- \\
\hline $\begin{array}{l}\text { Prior Month Silent-Alarm } \\
\text { Incidents }\end{array}$ & $\begin{array}{l}\text { Number of silent-alarm events transmitted from the operator's bus to the dispatch } \\
\text { center during the 30-day period prior to the assigned workday. }\end{array}$ & $\begin{array}{c}.01 \\
(.11)\end{array}$ & -- \\
\hline $\begin{array}{l}\text { Prior Month Work-Rule } \\
\text { Violations }\end{array}$ & $\begin{array}{l}\text { Number of work-rule violations involving the operator during the 30-day period prior } \\
\text { to the assigned workday }\end{array}$ & $\begin{array}{l}.002 \\
(.04)\end{array}$ & $\begin{array}{c}.24 \\
(.53) \\
\end{array}$ \\
\hline $\begin{array}{l}\text { Prior Month Property- } \\
\text { Damage Incidents }\end{array}$ & $\begin{array}{l}\text { Number of incidents involving property damage reported by the operator during the } \\
\text { 30-day period prior to the assigned workday }\end{array}$ & $\begin{array}{l}.006 \\
(.07)\end{array}$ & -- \\
\hline $\begin{array}{l}\text { Prior Month "Fit-for- } \\
\text { Duty" Incidents }\end{array}$ & $\begin{array}{l}\text { Number of reported (e.g., by passengers, field supervisors) "Fit-for-Duty" incidents } \\
\text { involving the operator during the 30-day period prior to the assigned workday }\end{array}$ & $\begin{array}{l}.003 \\
(.05)\end{array}$ & $\begin{array}{l}.19 \\
(.45) \\
\end{array}$ \\
\hline $\begin{array}{l}\text { Customer Complaints \& } \\
\text { Commendations }\end{array}$ & & & \\
\hline $\begin{array}{l}\text { Prior Month Complaints: } \\
\text { Public Relations }\end{array}$ & $\begin{array}{l}\text { Number of "unprofessional conduct" complaints involving the operator reported to } \\
\text { Customer Relations during the 30-day period prior to the assigned workday }\end{array}$ & $\begin{array}{l}.15 \\
(.46)\end{array}$ & -- \\
\hline $\begin{array}{l}\text { Prior Month Complaints: } \\
\text { Unsafe Operation }\end{array}$ & $\begin{array}{l}\text { Number of incidents involving unsafe vehicle operation by the operator reported to } \\
\text { Customer Relations during the 30-day period prior to the assigned workday }\end{array}$ & $\begin{array}{l}.07 \\
(.28) \\
\end{array}$ & $\begin{array}{l}.01 \\
(.09)\end{array}$ \\
\hline $\begin{array}{l}\text { Prior Month Complaints: } \\
\text { Service Delivery }\end{array}$ & $\begin{array}{l}\text { Number of complaints reported to Customer Relations involving a service delivery } \\
\text { problem (e.g., missed stops and pass-ups, early departures) by the operator during the } \\
\text { 30-day period prior to the assigned workday }\end{array}$ & $\begin{array}{l}.04 \\
(.23)\end{array}$ & $\begin{array}{l}.01 \\
(.08)\end{array}$ \\
\hline $\begin{array}{l}\text { Prior Month } \\
\text { Commendations: Stop } \\
\text { Announcements }\end{array}$ & $\begin{array}{l}\text { Number of commendations reported to Customer Relations involving the operator's } \\
\text { announcement of stops over the bus intercom }\end{array}$ & $\begin{array}{l}.19 \\
(.58)\end{array}$ & -- \\
\hline $\begin{array}{l}\text { Prior Month } \\
\text { Commendations: Other }\end{array}$ & $\begin{array}{l}\text { Number of commendations of the operator for all other reasons reported to Customer } \\
\text { Relations during the 30-day period prior to the assigned workday }\end{array}$ & $\begin{array}{c}.12 \\
(.40) \\
\end{array}$ & $\begin{array}{l}.03 \\
(.21)\end{array}$ \\
\hline Sample Size & Number of operator-days & 390,275 & 42,083 \\
\hline
\end{tabular}





\section{SO OTREC \\ AND EDUCATION CONSORTIUM}

P.O. Box 751

Portland, OR 97207

OTREC is dedicated to stimulating and conducting collaborative multi-disciplinary research on multi-modal surface transportation issues, educating a diverse array of current practitioners and future leaders in the transportation field, and encouraging implementation of relevant research results. 